\title{
nan \\ Biomarker Development in Cardiology: Reviewing the Past to Inform the Future
}

\author{
Katharine A. Kott ${ }^{1,2,3}$, Michael Bishop ${ }^{4}$, Christina H. J. Yang ${ }^{3}$, Toby M. Plasto ${ }^{3} \mathbb{D}$, Daniel C. Cheng ${ }^{3}$, \\ Adam I. Kaplan ${ }^{3} \mathbb{D}$, Louise Cullen ${ }^{5}$, David S. Celermajer ${ }^{3,6,7}$, Peter J. Meikle ${ }^{8} \mathbb{D}$, Stephen T. Vernon ${ }^{1,2,3}$ \\ and Gemma A. Figtree ${ }^{1,2,3, *}$
}

1 Cardiovascular Discovery Group, Kolling Institute of Medical Research, University of Sydney, St Leonards 2065, Australia; katharine.kott@sydney.edu.au (K.A.K.); steve.vernon@gmail.com (S.T.V.)

2 Department of Cardiology, Royal North Shore Hospital, St Leonards 2065, Australia

3 Sydney Medical School, University of Sydney, Camperdown 2050, Australia; hyan2234@uni.sydney.edu.au (C.H.J.Y.); tpla0842@uni.sydney.edu.au (T.M.P.); dche9126@uni.sydney.edu.au (D.C.C.); akap9401@uni.sydney.edu.au (A.I.K.); david.celermajer@health.nsw.gov.au (D.S.C.)

4 School of Medicine and Public Health, University of Newcastle, Kensington 2033, Australia; michael.bishop@uon.edu.au

5 Emergency and Trauma Centre, Royal Brisbane and Women's Hospital, Herston 4029, Australia; louise.cullen@health.qld.gov.au

6 Department of Cardiology, Royal Prince Alfred Hospital, Camperdown 2050, Australia

7 The Heart Research Institute, Newtown 2042, Australia

8 Baker Heart and Diabetes Institute, Melbourne 3004, Australia; peter.meikle@baker.edu.au

* Correspondence: gemma.figtree@sydney.edu.au; Tel.: +61-(2)-9926-4915

check for

updates

Citation: Kott, K.A.; Bishop, M.; Yang, C.H.J.; Plasto, T.M.; Cheng, D.C.; Kaplan, A.I.; Cullen, L.; Celermajer, D.S.; Meikle, P.J.; Vernon, S.T.; et al. Biomarker Development in Cardiology: Reviewing the Past to Inform the Future. Cells 2022, 11, 588. https://doi.org/10.3390/cells11030588

Academic Editors: Stephan von

Haehling and Tania Garfias-Veitl

Received: 30 December 2021

Accepted: 5 February 2022

Published: 8 February 2022

Publisher's Note: MDPI stays neutral with regard to jurisdictional claims in published maps and institutional affiliations.

Copyright: () 2022 by the authors Licensee MDPI, Basel, Switzerland. This article is an open access article distributed under the terms and conditions of the Creative Commons Attribution (CC BY) license (https:// creativecommons.org/licenses/by/ $4.0 /)$.

\begin{abstract}
Cardiac biomarkers have become pivotal to the clinical practice of cardiology, but there remains much to discover that could benefit cardiology patients. We review the discovery of key protein biomarkers in the fields of acute coronary syndrome, heart failure, and atherosclerosis, giving an overview of the populations they were studied in and the statistics that were used to validate them. We review statistical approaches that are currently in use to assess new biomarkers and overview a framework for biomarker discovery and evaluation that could be incorporated into clinical trials to evaluate cardiovascular outcomes in the future.
\end{abstract}

Keywords: cardiology; biomarker development; atherosclerosis; heart failure; acute coronary syndrome; statistical development

\section{Introduction}

The practice of modern cardiology utilizes multiple biomarkers and is an exemplar of biomarker discovery and use in medicine. While the drive to look for new and improved markers to benefit patients with cardiac disease is warranted, much research in this area over the past decade has had little impact on clinical care. Here, we review the development of some of the major cardiac biomarkers and discuss how they were first identified, what populations they were assessed in, and how their relationships to the conditions of interest were quantified. We have limited the scope of this review to protein-based markers, though similar approaches can and have been used with the extremely important lipid-based markers. Finally, we consider the future direction of biomarkers with new discovery platforms in well-phenotyped cohorts and the areas of remaining unmet need.

\section{Statistical Approaches to Assessing New Biomarkers}

Scientific discovery is the first step in biomarker development. Once a marker has been identified, characterized, and measured in the population of interest, statistically robust and clinically useful associations between the marker and the disease need to be established. If 
a significant association persists after adjustment for age and other established risk factors, it is often conveyed in relation to those with levels above a threshold as a relative risk in some form, such as a rate ratio, odds ratio, or hazard ratio [1]. Ultimately, the most compelling evidence comes from well-designed prospective studies demonstrating clinical utility [2], but this is not always performed prior to adoption in guidelines and practice [3].

Biomarker studies in cardiac disease have primarily used dichotomous outcomes, such as whether a person died or not, had a myocardial infarction or not, or had heart failure or not. This type of binary analysis generally reflects disease incidence rather than disease severity. Logistic regression analyses are used to evaluate the association of a biomarker with a dichotomous outcome. The distribution of the biomarker needs to be assessed for both cases and non-cases. If it is not normally distributed, transformation (commonly $\log 2$ ) frequently results in a sufficiently normal distribution to allow for analysis. Alternatively, if transformation is undesirable, or if the transformed data remain non-parametric, the biomarker can be categorized instead, commonly into quartiles, tertiles, or via a biologically plausible cut-off [4].

While some markers discussed below have been correlated with disease severity, the predictive utility of most of the biomarkers discussed in this article have been assessed using ROC curves, which are a visual representation of how well a model categorizes cases and non-cases. ROC curves have gained popularity in clinical science due to their intuitive interpretation and lack of dependency on units, granting the ability to make comparisons between different biomarkers or risk scores [4]. The area under the ROC curve, or the C-statistic, is equivalent to the likelihood that a randomly selected case is correctly given a higher rating or rank than a randomly selected non-case [5]. Its value ranges from 0.5 (no discrimination) to 1 (perfect discrimination) [6]. The C-statistic is a function of sensitivity and specificity, but it has limitations in clinical practice.

Clinically, we are often more interested in risk prediction, which is not captured by the C-statistic. The predictive value, or the post-test probability, is the likelihood of disease in patients with a positive test result [6]. This may be a more relevant measure, as it quantifies the likelihood of having the disease given the test result [6]. In cardiovascular medicine, we commonly use models which incorporate multiple variables (e.g., lipid levels, hypertension, and smoking) which would not result in a significant improvement in the ROC curve when assessed individually. The inclusion of novel biomarkers in risk prediction equations may not drastically alter the C-statistic; however, even incremental improvements can result in more accurate risk categorization and subsequent treatment.

Though evidence of association is a key step, it does not necessarily convey the clinical utility-or lack thereof-of measuring the new biomarker. This requires subsequent evaluation, usually in comparison with an existing model. Comparison between models involves assessment of the global measures of model fit, as well as measures of calibration, reclassification, and discrimination [7]. Calibration is the extent to which predicted probabilities agree with observed risk [6], and this can be assessed using the Hosmer-Lemeshow statistic [8,9], calibration-in-the-large, and a calibration plot [10]. Put simply, it is the frequency of which the estimation by the model reflects the real outcome [2]. Reclassification indicates whether the new model changes the estimate of an individual's risk enough to reallocate them to a different risk category [7]. Discrimination is the extent to which a model can separate cases and non-cases (i.e., those who have the disease and those who do not). Discrimination is most useful when dichotomous categorization is the goal, such as in diagnostic testing, and is usually represented by the area under the receiver operating characteristic (ROC) curve, or the C-statistic [5,6].

In recent decades, novel ways to assess improvement in risk prediction have been proposed. Assessing reclassification has become a popular way to assess novel markers and models, but it has limitations [11]. For example, a reclassification when a novel factor is included in a risk model may be accurate and lead to more appropriate treatment for some patients, but it may also incorrectly reclassify some patients who will derive no benefit from this reclassification. For this reason, net reclassification improvement (NRI) [11] was 
developed to reward correct reclassification and penalize incorrect reclassification [4]. Extending this further, integrated discrimination improvement (IDI) is the difference between the integral of sensitivity and the integral of one minus specificity over all possible cut-off values [12]. Like the ROC, the IDI is a measure of the corrected average sensitivity. Its utility differs from the NRI, as it does not require risk categories for reclassification, which is useful when established risk cut-offs do not exist [11].

Another approach to evaluating the utility of novel biomarkers is decision tree analysis modeling $[3,13]$. This approach may be more appropriate when the goal is to analyze all logical diagnostic and treatment strategies in population subgroups, which are often categorized using already established cut-offs [3]. Decision tree analysis modeling allows for the comparison of multiple strategies, which may be more appropriate when optimizing models that use multiple variables. A recent meta-analysis used decision tree analysis to predict the severity and mortality in COVID-19 patients using known biomarkers [13], and interestingly, the best model incorporated age, troponin, and aspartate aminotransferase. However, further research is needed with prospective studies of this type of modeling. An overview of an integrated approach to biomarker discovery is presented in Figure 1.

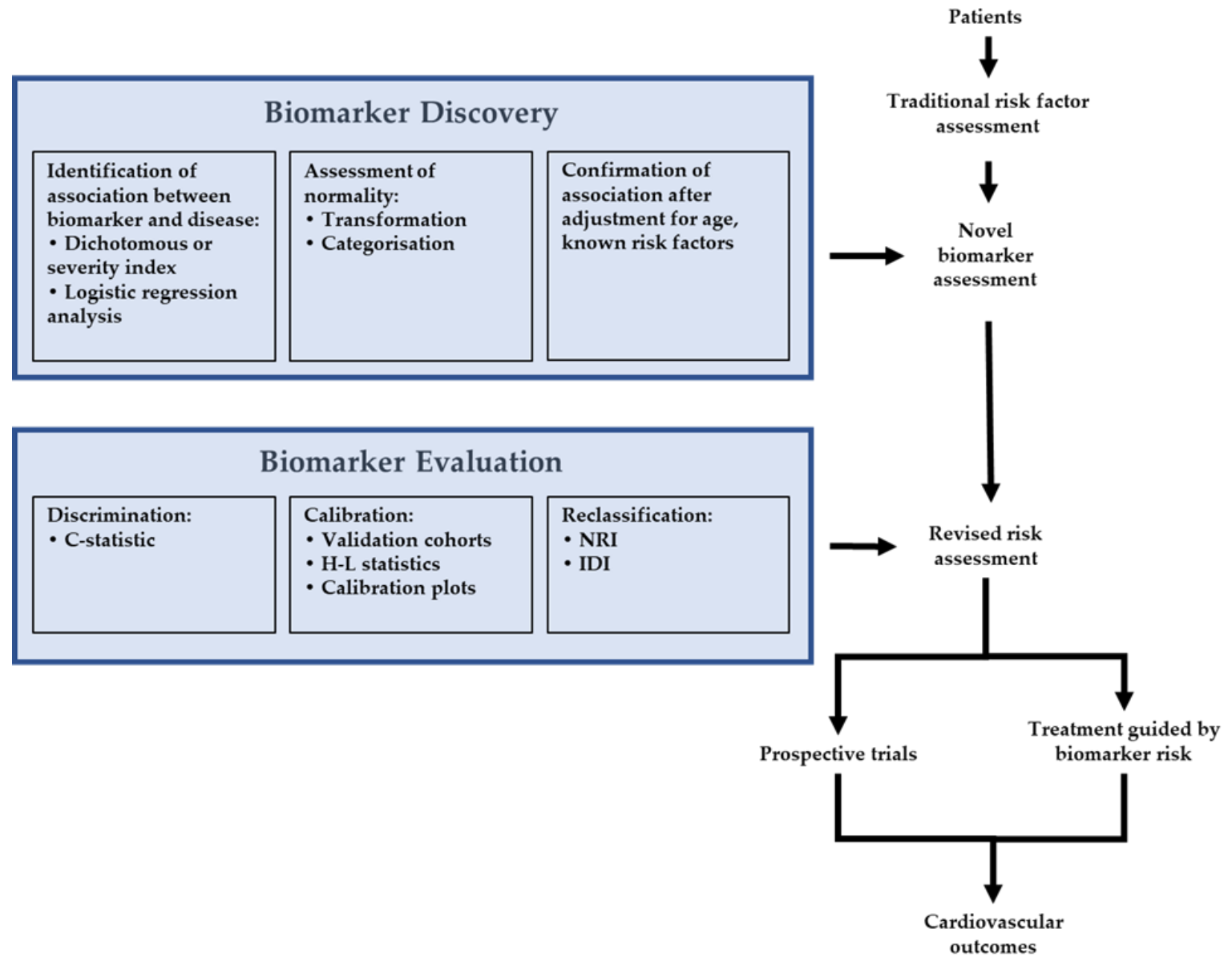

Figure 1. Framework for biomarker discovery, evaluation, and incorporation into clinical trials. Abbreviations: $\mathrm{H}-\mathrm{L}=$ Hosmer-Lemeshow; NRI = net reclassification index; IDI = integrated discrimination improvement.

\section{The History of Biomarker Development in Cardiovascular Disease}

The earliest reports of success of blood-based biomarkers providing clinical utility for cardiovascular disease were focused on improving the diagnosis of myocardial infarction (MI) and acute coronary syndrome (ACS). The first biomarkers for MI were identified in the 1950s (Figure 2). Serum glutamic oxaloacetic transaminase, now known as aspartate aminotransferase (AST), was first followed by lactate dehydrogenase (LDH) [14]. While 
these markers were indeed elevated in acute myocardial infarction (AMI) [15-19], they suffered from a lack of cardiac specificity [20], and the hunt was on to find more specific markers reflecting myocardial insult. This became particularly important with the evolution of MI treatments, including lytic therapy, where directing the right treatment to the right patient became critical. Over time, additional markers have emerged for reflecting heart failure and vascular inflammation, which are discussed below.

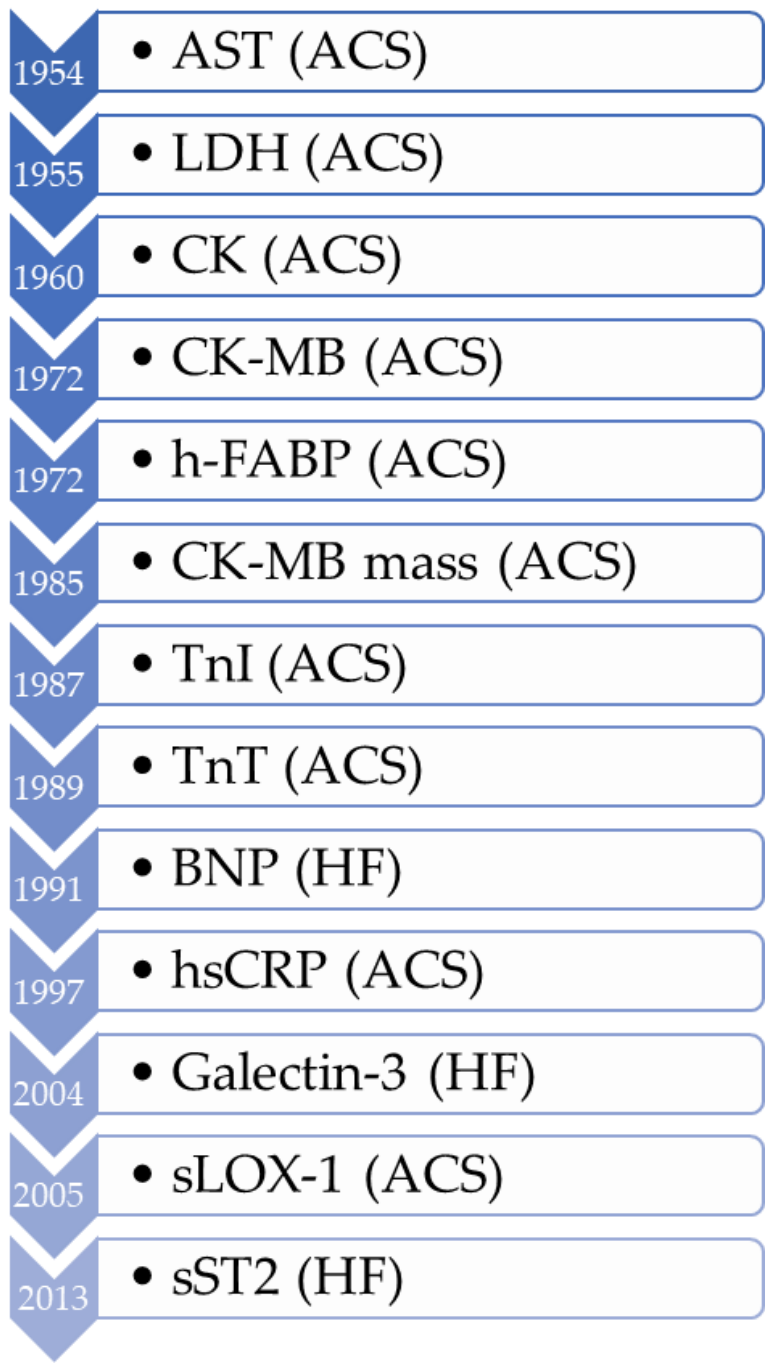

Figure 2. Timeline of biomarker development in cardiology. Abbreviations: AST = aspartate aminotransferase; $\mathrm{ACS}=$ acute coronary syndromes; $\mathrm{LDH}=$ lactate dehydrogenase; $\mathrm{CK}=$ creatine kinase; $\mathrm{CK}-\mathrm{MB}=$ myocardial creatine kinase isoenzyme; h-FABP = heart-type fatty acid binding protein; $\mathrm{TnI}=$ troponin $\mathrm{I} ; \mathrm{TnT}=$ troponin $\mathrm{T} ; \mathrm{BNP}=$ brain natriuretic peptide; hsCRP = high-sensitivity C-reactive protein; sLOX-1 = soluble lectin-like oxidized low-density lipoprotein receptor-1; sST2 = soluble suppression of tumorigenesis-2.

Summary data overviewing each biomarker's indication, reference ranges and the statistical methods used in biomarker development are listed in Table 1. Information for each marker relating to time sampling, time dynamics and non-cardiac causes of biomarker elevations are outlined in Table 2. The recommendations for each biomarker from the AHA/ACC and ESC guidelines, including level of evidence and class of recommendation, is summarized in Table 3. 


\subsection{Acute Coronary Syndrome (ACS) Biomarkers}

\subsubsection{Creatine Kinase}

Creatine kinase $(\mathrm{CK})$ is an enzyme found in all muscle cells that catalyzes the reaction between adenosine triphosphate (ATP) and creatinine in the production of cellular energy, and it is released into circulation when myocytes are damaged. It was first proposed as a potential biomarker for myocardial infarction in 1960 [21], followed by a study in 1963 comparing 120 patients with AMI to 34 controls in the pre-angiography era [22]. Subsequent studies showed that CK was more specific for coronary occlusion than AST, particularly when looking at patient populations with myocardial damage and hepatic parenchymal damage or acute pancreatitis [23], as well as in patient populations with differing presentations suggestive of AMI, non-AMI heart diseases, and non-cardiac diseases including pulmonary embolism, primary hepatic disease, and cancer [24].

The discovery of isoenzymes of creatine kinase and high concentrations of the cardiac muscle-specific isoform CK-MB in the 1970s [25-27] led to the development of assays that confirmed the elevation of circulating CK-MB following myocardial infarction [28-30]. Studies examined populations suspected of acute myocardial infarction [31], populations with confirmed or suspected myocardial infarctions, indications for cardiac catheterization or non-cardiac surgery [32], and populations admitted to the acute cardiac unit of Mount Sinai Hospital [33]. In most patients, CK-MB was elevated 4-6 h post-infarction [34,35] and returned to the baseline within 36-48 $\mathrm{h}$ [19].

These initial studies into CK and CK-MB primarily reported their results by comparing the means between groups and of the control samples without detailed analyses between groups. These data were reviewed to identify the normal range for $\mathrm{CK}-\mathrm{MB}$, and the diagnostic thresholds for elevated CK-MB were defined using the upper limit of the standard [29,36-38]. In the 1990s, early diagnosis of MI was improved by assays of subforms of CK-MB [34], as reflected by the use of the C-statistic, which has since become the common practice for assessing new biomarkers [35]. Testing of the total CK in the modern laboratory is generally performed by spectrophotometry, with isoform analysis conducted either by electrophoresis or immunoassay [34]. While CK-MB had a long period of clinical utility, it is no longer the biomarker of choice for primary diagnosis of ACS.

\subsubsection{Heart Fatty Acid-Binding Proteins (h-FABP)}

The search for biomarkers of ACS with improved sensitivity and specificity continued despite the success of CK-MB. Initially described in 1972, fatty acid-binding proteins (FABP) are responsible for the cytoplasmic transport of unsaturated fatty acids in various organs, including the kidneys, myocardium, intestines, and adipose tissues [39]. Heart-type FABP (h-FABP) accumulated interest as a potential biomarker of ACS following observation of its release from ischemic myocardial cells in rats [40].

h-FABP has been recommended as a marker for ACS in patients presenting shortly after symptom onset. Different enzyme-based immunoassays to measure h-FABP found that its plasma levels peaked earlier than CK-MB and LDH, with elevations detectable at approximately 5-10 h following the onset of ACS symptoms [41,42]. Two separate studies investigating patients with acute chest pain and suspected AMI published in 2004 and 2008 found that h-FABP had a higher sensitivity but lower specificity than early troponin $\mathrm{T}$ assays for diagnosing AMI within 2 and $4 \mathrm{~h}$ of symptom onset $[43,44]$. The h-FABP concentration reaches its peak $6 \mathrm{~h}$ after symptom onset and returns to its baseline level by $24 \mathrm{~h} \mathrm{[45].} \mathrm{At} \mathrm{present,} \mathrm{no} \mathrm{formal} \mathrm{recommendation} \mathrm{exists} \mathrm{for} \mathrm{a} \mathrm{clinically} \mathrm{useful} \mathrm{threshold}$ level for h-FABP. A cut-off of $4 \mathrm{ug} / \mathrm{L}$ has been suggested based on calculations of the area under the receiver operating characteristic (ROC) curve, or the C-statistic, in a number of studies [44,46,47].

While high-sensitivity troponin assays remain dominant in current clinical practice (discussed below), there may still be a role for h-FABP in point-of-care testing in primary healthcare, urgent care centers, and emergency departments [47] and as part of a decision tree in combination with high-sensitivity troponins [48]. However, recent studies have 
found that h-FABP is not a reliable biomarker for ACS [49], even as part of a clinical decision rule with multivariable analyses [50]. More research is required to determine how h-FABP could be meaningfully utilized in a clinical setting.

\subsubsection{Troponin}

While CK-MB was found to be a reasonable biomarker for AMI, there was a need for markers that could be detected soon after the onset of symptoms which could be utilized either to confirm or refute the diagnosis of AMI, and this led to interest in the troponins. The troponin complex consists of three subunits that work collectively to displace tropomyosin from the cross-bridge binding sites on actin [51,52]. The subunits were first characterized as cardiac proteins in 1965 [51]. Troponin C (TnC) has a role in binding to calcium ions, eliciting a conformational change in troponin I (TnI), which is responsible for inhibiting ATPase [52]. Troponin $\mathrm{T}$ (TnT) binds to tropomyosin, and actin-myosin binding and subsequent muscle contraction result. While TnC is present in both skeletal and cardiac muscles, TnT and TnI are specific to cardiac myocytes and remain the most specific biomarkers for myocardial tissue damage.

The first TnI immunoassay was developed in 1987 [53]. This assay detected mean peak TnI levels of $112 \mathrm{ng} / \mathrm{mL}$ in patients with AMI and $<10 \mathrm{ng} / \mathrm{mL}$ in those without $18 \mathrm{~h}$ after estimated infarction onset [53]. Similar results were later observed for a TnT immunoassay [54]. Further studies in the 1990s provided compelling evidence for the utility of immunoassays for TnT [55-59] and TnI [60,61], and these were strongly advocated for [38,62].

In the year 2000, experts recommended the upper limit for positive results to be set to the 99th percentile compared with the control population three standard deviations above the population's mean [63]. Subsequently, the International Federation of Clinical Chemistry advised a control sample size of 300 to increase the precision of the numerous troponin assays available [64]. The current universal definition of AMI utilizes these recommendations [65]. There is still no consensus, however, on what defines a "normal" population in which to determine the 99th percentile [65]. The detection of a rise or fall in the troponin level is necessary for the diagnosis of AMI [65]. This requires serial measurement of troponin levels, but defining a pathological delta is assay-dependent [65]. The first sample should be taken at the time of presentation, and a negative result is routinely followed by repeat testing after 3-6 h, although high-sensitivity assays may allow for a rule-in diagnosis by $2 \mathrm{~h}$ [65]. Further measurement after $6 \mathrm{~h}$ may be required in ongoing ischemic episodes or in high-risk patients [65].

The last decade has seen continuing improvements in the sensitivity of both troponin I and troponin T, with high-sensitivity immunoassays available in the lab and recently in point-of-care devices [66,67]. Prospective studies have demonstrated the major advantages of the high-sensitivity assays as a part of algorithms for the rapid ruling out of ACS in chest pain patients presenting to the emergency department, helping avoid unnecessary hospitalization without compromising patient safety [68-73]. While serial testing strategies have long been the norm, early rule-out pathways using a single high-sensitivity troponin test under a threshold value ( $<5 \mathrm{ng} / \mathrm{L}$ for hsTnI) have been demonstrated to be safe if it has been at least $2 \mathrm{~h}$ since symptom onset [74].

However, with the advent of high-sensitivity assays, a greater proportion of the general population have measurable levels of troponin in their blood [75]. Some of these elevations are in an expected range of biological variability, but there is also troponin release after strenuous exercise [76] (including stress testing [77]) and rapid atrial pacing in patients with coronary artery disease [78]). Patients with underlying cardiovascular disease have significantly higher troponin levels at baseline when measured with highsensitivity assays [79], and a study of apparently healthy participants in the community where increasingly strict selection criteria were applied resulted in progressively lower 99th percentile upper reference limits [80]. A recent study found that baseline high-sensitivity troponin was an independent predictor of coronary heart disease death or pending AMI, even in levels within the normal range [81]. Interestingly, in participants treated with 
statin therapy, those who had a significant decrease in high-sensitivity troponin levels in response to treatment had the greatest reduction in non-fatal MI and death from coronary artery disease, suggesting a role for high sensitivity troponin in treatment monitoring [81]. This variation within the "normal" range has led to interest in high-sensitivity troponin as a biomarker for CV risk prediction outside the ACS sphere. Advocates highlight that troponin has many features of a good cardiovascular risk biomarker, such as detectably elevated levels in high-risk patients, dynamic reductions in those on risk factor treatment, and additive value to existing risk scoring systems [82]. While there are some challenges, such as the marker's narrow concentration ranges which correlate with risk, further studies may demonstrate that this is a cost-effective biomarker which could be easily used to supplement existing risk assessment mechanisms.

Outside of these variations within the low-to-normal ranges-which may prove to be useful for non-ACS risk stratification in the future-the major limitation of troponin relates to its inability to distinguish the underlying pathology, leading to troponin elevation. The biomarker is unable to distinguish between an atherosclerotic event in a major epicardial coronary artery versus a type II myocardial infarction, or "MI mimic", such as myopericarditis or Takotsubo cardiomyopathy. Future efforts to develop more specific markers may provide physicians with a combined tool kit to improve triaging of patients in invasive investigations and avoiding the catheter laboratory for those where percutaneous intervention is not required.

\subsubsection{Soluble Lectin-Like Oxidized Low-Density Lipoprotein Receptor-1 (sLOX-1)}

Discovered in the late 1990s, the lectin-like oxidized low-density lipoprotein receptor-1 (LOX-1) is a 50-kDa transmembrane glycoprotein which was initially reported as a receptor for oxidized low-density lipoprotein (LDL) [83]. LOX-1 has no binding activity toward native LDL [84], but oxidized or otherwise modified LDL binds to LOX-1 and triggers secretion of chemokines, pro-inflammatory molecules [85], and reactive oxygen species [86], and LOX signaling has been implicated in activation of the NLRP3 inflammasome [87,88]. LOX-1 can be expressed on the surface of endothelial cells, smooth muscle cells, fibroblasts, platelets, and macrophages [89]. LOX-1 expression is undetectable in normal vascular tissue but increases in the presence of atherosclerotic plaque formation $[90,91]$. The soluble form of LOX-1 (sLOX-1) is released when the extracellular domain of the receptor is cleaved, the specific mechanism of which is still being investigated [84]. Pro-inflammatory signaling via TNF-alpha appears to prime macrophages for sLOX-1 release, however, and this is enhanced by CRP [92] as well as IL-18 [93].

Clinically, sLOX-1 release has been studied as a biomarker for acute coronary syndrome with some significant results. Using enzyme-based immunoassays, sLOX-1 has been found to be elevated in patients who have had any type of ACS [94-96], to be raised before any other biomarker [96], and to have better sensitivity and specificity than current biomarkers, including hsCRP $[94,96]$. There have also been studies showing that sLOX-1 levels are higher in patients with ruptured plaque [97], in more proximal coronary lesions [98], and in more complex lesions [99]. There is also evidence that elevation of sLOX-1 beyond a certain threshold correlates with adverse clinical outcomes following acute coronary syndrome [100-102].

The peak elevation of sLOX-1 in STEMI patients occurs earlier and persists for longer (up to $24 \mathrm{~h}$ after presentation) compared with other biomarkers of ACS [96]. The diagnostic levels of sLOX-1 still need further evaluation, however, with reports variably using cutoffs of 91.0-131.7 pg/mL [95-97] for ACS with plaque rupture, based on analyses of the C-statistic. Additionally, while sLOX-1 levels are elevated earlier than high-sensitivity troponin in ST-elevation myocardial infarction (STEMI) [96], the clinical utility of this is limited, as the majority of patients are diagnosed based on clinical history and ECG findings prior to the return of even the most rapid pathology results. It is yet to be determined whether the specificity of sLOX-1 for atherosclerotic-related events may have benefits in the management of patients with MI-mimics such as myocarditis or Takotsubo cardiomyopathy. 


\subsection{Heart Failure (HF) Biomarkers}

\subsubsection{Natriuretic Peptides}

While both CK-MB and troponin aided the diagnosis of myocardial infarction, it took more time to develop markers for heart failure (HF). A peptide from homogenized rat atrial tissue that exhibited strong natriuretic and chloriuretic effects was described in 1981 [103]. This peptide was named atrial natriuretic factor (ANF), and in 1985, it was postulated that it had a role in the control of blood pressure [104]. Circulating levels of ANF (later renamed to atrial natriuretic peptide (ANP)) were found to be elevated in heart failure [105], and it became an important diagnostic and prognostic biomarker [106]. The $\mathrm{N}$ terminus of pro-ANP (NT-ANP) is the inactive portion of the prohormone and is cleared from circulation more slowly, allowing for easier detection in the serum [106]. Subsequently, a novel compound in porcine brains was identified that exhibited similar effects to ANF, aptly named brain natriuretic peptide (BNP) [107]. It was later found that BNP was also present in the hearts of both pigs [108] and rats [109]. The amino acid sequence of human BNP was rapidly identified [110], and shortly afterward, a radioimmunoassay was developed, identifying BNP in human heart samples and revealing the ventricles as the major site of BNP secretion [111].

Initial studies showed that the levels of BNP in plasma were raised in patients with HF [111] and that the level of BNP increased with the severity of heart failure [111,112]. $\mathrm{BNP}$ was found to have a higher specificity and positive predictive value for a diagnosis of HF than ANP [113]. A subsequent systematic review found BNP to be a more accurate diagnostic marker for heart failure than NT-ANP [114]. A preliminary assessment of healthy subjects showed that the mean BNP level $( \pm \mathrm{SD})$ was $1.8 \pm 1.0 \mathrm{pmol} / \mathrm{L}$ and that in 8 subjects with HF, the median BNP level was 30.5 pmol/L [115].

This was followed up by larger cohort studies [116-118], which confirmed significantly elevated levels of BNP in patients with systolic dysfunction and identified the strong negative predictive value of a low BNP result. However, BNP's elevation in other conditions such as atrial fibrillation [117] was also identified, and thus echocardiography is still considered required for the diagnosis of HF [119].

BNP is cleaved from the C-terminal end of its prohormone, pro-BNP. The N-terminal fragment, N-terminal pro-BNP (NT-proBNP), is also released into circulation [120]. NTproBNP has been found to be comparable to BNP in patients with an impaired left ventricle ejection fraction $[121,122]$. NT-proBNP results have been shown to be valuable for diagnosis of HF in patients presenting acutely with dyspnea [123-126], as well as correlating with prognostic outcomes in acute and chronic HF [126-130]. Both BNP and NT-proBNP are detectable using rapid immunoassays, but the potential advantages of NT-proBNP include its greater range of values [131] and longer half-life [132]. BNP and NT-proBNP measures are strongly correlated (correlation coefficient of 0.81 ), and in patients with HF with a reduced ejection fraction, the median ratio of NT-proBNP/BNP was 6.25/1, which was consistent across BNP deciles [133]. Interestingly, this ratio was found to be significantly higher in patients of an older age, male sex, higher creatinine, and atrial fibrillation and lower in those with obesity and a history of myocardial infarction [133]. Further research into whether different cut-offs should be used in certain clinical conditions (e.g., atrial fibrillation or renal impairment) is ongoing. Recent Australian guidelines recommend clinical use of natriuretic peptides, describing strong evidence that they are useful in diagnosing suspected HF but only weak evidence that they have utility as prognostic factors [134]. A plasma BNP level of $<100 \mathrm{ng} / \mathrm{L}$ or an NT-proBNP level of $<300 \mathrm{ng} / \mathrm{L}$ exclude heart failure [134]. Rigid cut-offs for positive BNP and NT-proBNP results, however, are limited in accuracy due to the multiple factors that influence natriuretic peptide levels, including age, kidney function, the presence of atrial fibrillation, sex, and weight [134]. For these reasons and others, the ESC guidelines use the test as a rule-in test rather than a rule-out test, including $\mathrm{BNP} \geq 35 \mathrm{pg} / \mathrm{mL}$ or $\mathrm{NT}$-proBNP $\geq 125 \mathrm{pg} / \mathrm{mL}$ as part of the diagnostic algorithm for heart failure [135]. Sex-specific differences in natriuretic peptide 
levels have been detected, but these differences have not been included in diagnostic or risk prediction models [136].

BNP has also been shown to have clinical utility in guiding management of heart failure, particularly regarding fluid volume overload. The utility of BNP and NT-proBNP in guiding management of $\mathrm{HF}$ is still unclear, with some evidence suggesting biomarkerguided therapy reduces mortality [137] and some evidence finding no difference compared with symptom-guided management [138,139].

\subsubsection{Galectin-3}

There was significant interest in galectin- 3 as a biomarker when it was first implicated in HF in 2004, when it was found to be specifically overexpressed in the myocardium of Ren-2 rats that would go on to develop HF [140]. Additionally, it was demonstrated that galectin-3 promoted cardiac fibroblast proliferation and increased collagen I deposition, leading to fibrosis [140]. Galectin-3 was found to be reliably measured in enzyme-based immunoassays which do not cross-react with other members of the galectin family [141].

Initial clinical studies showed that while galectin-3 lacked utility for HF diagnosis, galectin-3 was an independent prognostic factor for all-cause mortality and HF hospitalization, suggesting it had use as a prognostic biomarker [141-143]. A major study indicated that the baseline galectin-3 measurements were sufficient, with repeat levels after 6 months granting no further prognostic information [141].

Multiple studies on galectin-3 in HF followed. A 2017 meta-analysis reviewed 18 studies with a total of 32,350 patients [144]. After adjustment for age, sex, BNP, renal function, and diabetes, they calculated hazard ratios (HRs) of 1.10 (95\% CI: 1.05-1.14) for all-cause mortality, 1.22 (95\% CI: 1.05-1.39) for cardiovascular related mortality, and 1.12 (95\% CI: 1.04-1.21) for risk of HF with each 1 standard deviation rise in galectin-3 concentrations. In specific analysis for cardiovascular mortality, they calculated an HR of 1.44 (95\% CI: $1.09-1.79)$ for HF patients for every 1 standard deviation increase in galectin-3 concentrations.

Other studies have typically analyzed dichotomous outcomes using a cut-off value of $17.8 \mathrm{ng} / \mathrm{mL}$ for galectin-3 when assessing HF, with a significantly increased risk of rehospitalization and mortality due to HF when levels exceeded $17.8 \mathrm{ng} / \mathrm{mL}[144,145]$, calculated using the C-statistic. Several prospective studies support these findings [146-148].

In addition to its use as a biomarker for HF prognosis, reports have increasingly suggested that galectin-3 may also provide a possible therapeutic target in HF due to its role in the development of myocardial fibrosis and diastolic dysfunction [149-151]. Further research into this area is ongoing.

However, due to some limitations, the use of galectin- 3 in clinical care of patients with or at risk of heart failure is not routine. Galectin-3 levels are elevated in a number of other fibrotic diseases, including liver cirrhosis [152,153] and pulmonary fibrosis [154], as well as in patients with renal insufficiency [155]. These findings of elevation in other fibrotic processes reduce its specificity as a cardiac biomarker. Furthermore, the effect of age on galectin-3 levels is inconclusive thus far [144].

\subsubsection{Suppression of Tumorigenesis-2 (sST2)}

Suppression of tumorigenesis-2 (ST2), first reported in 1989 [156], is a receptor related to IL-1 with two main isoforms: transmembrane or cellular (ST2L) and soluble or circulating (sST2) [157]. IL-33 is the ligand of ST2 [158], which is secreted by most cells in response to damage [159], including myocardial stress [160]. The IL-33/ST2 system is cardioprotective and reduces myocardial fibrosis, prevents cardiomyocyte hypertrophy, reduces apoptosis, and improves myocardial function $[157,161,162]$. sST2, however, is thought to be a decoy receptor that sequesters IL-33, negating its cardioprotective and antihypertrophic effects $[157,161]$. sST2 concentrations measured by an enzyme-based immunoassay are elevated in patients with AMI and acute HF and correlate with the infarct size and cardiac dysfunction [163], hemodynamic decompensation [164], and risk of death [165]. 
sST2 has generated interest as a novel biomarker in both acute and chronic HF [166,167]. sST2 concentrations have been found to be higher in chronic HF than healthy patients [168], and sST2 is thought to be a prognostic marker for worse outcomes [169]. A recent metaanalysis has found that SST2 is a predictor of both all-cause and CV death in chronic HF outpatients [170]. In acute HF, sST2 concentrations are higher [171], and sST2 was found to be the strongest predictor of death at 1 and 4 years [165], with similar prognostic capabilities seen in patients with HF with preserved ejection and with a reduced ejection fraction [172].

However, baseline sST2 concentrations have failed to predict incident HF or cardiovascular events, but they do predict all-cause mortality [173]. sST2 was found in one large study to be the biomarker that added the most prognostic value to clinical risk models, predicting short-term and 1-year mortality in acute decompensated HF [174], using the difference in the C-statistic as well as computing the net reclassification improvement (NRI) and integrated discrimination improvement (IDI). sST2 may also play a role in monitoring therapy for HF [166]. sST2 levels have been observed to decrease in patients treated with beta blockers [175] and valsartan [176], and spironolactone treatment was beneficial in patients with elevated sST2 [177].

Clinical use of sST2 is increasing. Measures of biomarker utility including calibration, reclassification, and discrimination have been improved with the addition of sST2 to existing models [178-181]. The 2017 American Heart Association (AHA) guidelines support the use of an sST2 assay for prognosis and risk stratification in CHF patients, with a Class $\mathrm{IIb}$, level of evidence: B-NR (non-randomized) recommendation [182].

\subsection{Atherosclerosis Risk \\ High-Sensitivity C-Reactive Protein (hsCRP)}

The focus of most early biomarker work was related to the diagnosis of AMI and heart failure, but there has been a paucity of markers for atherosclerosis and coronary artery disease itself. Instead, physicians and their patients rely on risk factor algorithms to assess who may be at high risk of an acute cardiovascular event. This is an area that is likely to be transformed over the next decade. Inflammation is known to play a key role in atherosclerosis. As such, investigators have dedicated substantial efforts to identifying a potential role for high-sensitivity C-reactive protein (hsCRP) measures. This sensitive enzyme-based immunoassay has been developed to be capable of detecting low levels of the molecule CRP, which is an acute phase reactant released by the liver in response to inflammation. This allows discrimination between values that were previously considered to be in the "normal range" using the older, less-sensitive methodology. Measurements of CRP have been tentatively linked to cardiac health since the 1980s, with studies finding that CRP levels were raised in patients who had been diagnosed with AMI or angina $[183,184]$.

Baseline CRP measurements have been found to be higher in men who went on to have an AMI (1.51 vs. $1.13 \mathrm{mg} / \mathrm{L})$ or stroke (1.38 vs. $1.13 \mathrm{mg} / \mathrm{L})$ compared with men who did not, and the risk of AMI increased with each quartile increase of CRP levels [185]. These findings were expanded upon in post-menopausal women, and hsCRP was found to correlate most strongly with cardiovascular events compared with 11 other markers [186].

Increased baseline CRP results have been found to correlate independently with subsequent risk of cardiovascular events in a number of prospective trials in the late 1990s $[187,188]$. The risk increase associated with elevated CRP in the Framingham study remained statistically significant across CRP quartiles, independent of other risk factors [188].

More recent studies have examined whether identifying CRP levels would be a useful tool for clinical and pharmacological management. The JUPITER study examined the impact of statins on lowering hsCRP levels and future cardiovascular events. Statin therapy led to a reduction in levels of hsCRP in some participants, which in turn was associated with a reduced incidence of cardiovascular events [189]. In addition to inhibiting HMG-CoA reductase, statins are thought to inhibit the synthesis of isoprenoid intermediates of the mevalonate pathway, which may account for other proposed benefits of statins, including 
improvements in endothelial function, plaque stabilization, and reduced inflammation, as demonstrated by the reduction in hsCRP $[190,191]$.

The American Heart Association and United States Center for Disease Control have defined a normal level (low-risk) hsCRP as $<1.0 \mathrm{mg} / \mathrm{L}$, a moderately increased risk level as 1-3 mg/L, and high-risk levels as $>3.0 \mathrm{mg} / \mathrm{L}[192,193]$ based on the approximate levels in the general population [192]. Various studies have categorized hsCRP results into tertiles [194,195], quartiles [196], and quintiles [197] and computed the C-statistic [197]. While these data have proven convincing enough for hsCRP to now appear in many guidelines, hsCRP is not yet widely used in cardiovascular risk stratification models.

Table 1. Summary of biomarker indications, reference ranges, and statistical approaches used. Abbreviations: ACS = acute coronary syndrome; AST = aspartate aminotransferase; $\mathrm{AMI}=$ acute myocardial infarction; $\mathrm{LDH}=$ lactate dehydrogenase; $\mathrm{CK}=$ creatine kinase; $\mathrm{CK}-\mathrm{MB}=$ myocardial creatine kinase isoenzyme; h-FABP = heart-type fatty acid-binding protein; $\mathrm{TnI}=$ troponin I; $\mathrm{TnT}=$ troponin $\mathrm{T} ; \mathrm{BNP}=$ brain natriuretic peptide; hsCRP = high-sensitivity C-reactive protein; sLOX-1 = soluble lectin-like oxidized low-density lipoprotein receptor-1; sST2 = soluble suppression of tumorigenesis- 2 .

\begin{tabular}{|c|c|c|c|}
\hline Biomarker & Indication & Reference Range & Statistics \\
\hline CK-MB & AMI & $\begin{array}{l}>99 \text { th percentile of upper reference limit } \\
\text { of sex-specific controls for assay }[65] \\
\qquad 20-25 \mathrm{U} / \mathrm{I}[30,37] \\
\quad>30 \mathrm{U} / \mathrm{I}[29] \\
{\mathrm{CK}-\mathrm{MB}_{2}}^{\text {:CK-MB }} \text { ratio }>1.5[34,35]\end{array}$ & $\begin{array}{l}\text { Analysis of frequency distribution [29], } \\
\text { C-statistic [35] }\end{array}$ \\
\hline Troponin & AMI/CV Risk & $\begin{array}{l}>99 \text { th percentile of upper reference limit } \\
\text { for assay [65] }\end{array}$ & $\approx 3$ SDs above the mean for normal range [63] \\
\hline sLOX-1 & AMI & $>91.0-131.7$ pg/mL (suggested) [95-97] & C-statistic [95-97] \\
\hline h-FABP & AMI & $>4 \mathrm{ug} / \mathrm{L}[46,47]$ & C-statistic $[43,44,47]$ \\
\hline BNP & $\mathrm{HF}$ & $\begin{array}{l}\text { Rule out: }<100 \mathrm{ng} / \mathrm{L}[134] \\
\text { Rule in: }>400 \mathrm{ng} / \mathrm{L}[134]\end{array}$ & C-statistic $[114,116]$ \\
\hline NT-proBNP & $\mathrm{HF}$ & $\begin{array}{l}\text { Rule out: }<300 \mathrm{ng} / \mathrm{L}[134] \\
\text { Rule in: age }<50 ;>450 \mathrm{ng} / \mathrm{L}[134] \\
\text { Rule in: age } 50-75 ;>900 \mathrm{ng} / \mathrm{L}[134] \\
\text { Rule in: age }>75 ;>1800 \mathrm{ng} / \mathrm{L}[134]\end{array}$ & C-statistic $[198,199]$ \\
\hline Galectin-3 & $\mathrm{HF}$ & $>17.8 \mathrm{ng} / \mathrm{L}[144,145]$ & C-statistic [144-146] \\
\hline sST2 & $\mathrm{HF}$ & $>35$ ng/L [200,201] & C-statistic [202], NRI, and IDI [174] \\
\hline hsCRP & CV Risk & $\begin{array}{l}\text { High risk: }>3 \mathrm{mg} / \mathrm{L}[192,193] \\
\text { Increased risk: }>1 \mathrm{mg} / \mathrm{L}[203]\end{array}$ & $\begin{array}{c}\text { Tertiles [194,195], quartiles [196], quintiles } \\
\text { [197], and the C-statistic [197] }\end{array}$ \\
\hline
\end{tabular}


Table 2. Time sampling, time dynamics, and non-cardiac causes of altered levels of cardiac biomarkers. Abbreviations: $\mathrm{AF}=$ atrial fibrillation; $\mathrm{AKI}=$ acute kidney injury; $\mathrm{ALD}=$ alcoholic liver disease; $\mathrm{ARNI}=$ angiotensin receptor-neprilysin inhibitor; $\mathrm{BNP}=$ brain natriuretic peptide; $\mathrm{CK}-\mathrm{MB}=$ myocardial creatine kinase isoenzyme; $\mathrm{COPD}=$ chronic obstructive pulmonary disease; $\mathrm{DM}=$ diabetes mellitus; $\mathrm{HF}=$ heart failure; h-FABP = heart-type fatty acid-binding protein; hsCRP = high-sensitivity C-reactive protein; HTN = hypertension; $\mathrm{LVH}=$ left ventricular hypertrophy; NAFLD = non-alcoholic fatty liver disease; NT-proBNP = N-terminal pro-BNP; $\mathrm{PE}=$ pulmonary embolism; sLOX-1 = soluble lectin-like oxidized low-density lipoprotein receptor-1; sST2 = soluble suppression of tumorigenesis-2.

\begin{tabular}{|c|c|c|c|}
\hline Biomarker & $\begin{array}{c}\text { When to Take Sample (Time } \\
\text { Sampling) }\end{array}$ & $\begin{array}{l}\text { Biomarker Changes over } \\
\text { Time (Time Dynamics) }\end{array}$ & Non-Cardiac Causes of Altered Levels \\
\hline CK-MB & $\begin{array}{l}4-6 \mathrm{~h} \text { after symptom } \\
\text { onset }[34,35]\end{array}$ & $\begin{array}{l}\text { Peak occurs after } 16-30 \mathrm{~h}, \\
\text { returns to baseline by } \\
24-36 \mathrm{~h} \text { [204] }\end{array}$ & $\begin{array}{c}\text { Elevated in skeletal muscle injury [205], } \\
\text { vigorous exercise [206], stroke [207], } \\
\text { trauma patients [208], and kidney } \\
\text { disease [209,210]; } \\
\text { 1.2-2.6x higher 99th percentile in males } \\
\text { [211] and post-operatively in spinal } \\
\text { surgery [212] }\end{array}$ \\
\hline h-FABP & $\begin{array}{l}2-4 \mathrm{~h} \text { after symptom } \\
\text { onset }[43,44]\end{array}$ & $\begin{array}{l}\text { Peak occurs } 6 \mathrm{~h} \text { after } \\
\text { symptom onset, returns to } \\
\text { baseline by } 24 \mathrm{~h}[45]\end{array}$ & $\begin{array}{l}\text { Elevated in AKI [213], PE [214], stroke } \\
\text { [215], sepsis [216], acute HF [217], } \\
\text { NAFLD [218], smoking, and COPD [219] }\end{array}$ \\
\hline Troponin & $\begin{array}{c}\text { At presentation and then } 2-6 \\
\mathrm{~h} \text { later if the first result is } \\
\text { negative [65] }\end{array}$ & $\begin{array}{l}\text { Peak occurs at } 12-48 \mathrm{~h}[220] \\
\text { returns to baseline by } \\
14 \text { days [221] }\end{array}$ & $\begin{array}{l}\text { Elevated in sepsis [222], critical illness } \\
\text { [223], LVH [224], coronary vasospasm } \\
\text { [225], stroke [226], AF [227], heart failure } \\
\text { [228], myocarditis [229], dialysis patients } \\
\text { [230], males, black people, DM, and HTN } \\
\text { [231]; lower in smoking, alcohol use, and } \\
\text { statin use [231] }\end{array}$ \\
\hline sLOX-1 & At presentation [96] & $\begin{array}{l}\text { Peak is maintained from } \\
\text { presentation up to } 24 \mathrm{~h} \text { [96] }\end{array}$ & $\begin{array}{c}\text { Conflicting association with smoking } \\
{[95,232] \text { and not significantly correlated }} \\
\text { with lipids, diabetes, or hypertension } \\
{[94,95]}\end{array}$ \\
\hline $\mathrm{BNP}$ & $\begin{array}{c}\text { At presentation for acute } \\
\text { dyspnea }[116] \text { as a screening } \\
\text { tool }[117,118,233]\end{array}$ & $\begin{array}{c}\text { Levels remain elevated in } \\
\text { untreated HF; treatment may } \\
\text { lower levels to normal range } \\
\qquad[234,235]\end{array}$ & $\begin{array}{l}\text { Elevated in smokers [236] and renal } \\
\text { insufficiency }[237,238] \text {; lower in obesity } \\
\text { [239], even in patients with HF [240]; } \\
\text { degraded by neprilysin (ARNI therapy } \\
\text { causes BNP elevation) [241] }\end{array}$ \\
\hline NT-proBNP & $\begin{array}{l}\text { At presentation for acute } \\
\text { dyspnea [123-126] }\end{array}$ & $\begin{array}{l}\text { Levels remain elevated in } \\
\text { untreated HF; treatment may } \\
\text { lower levels to normal } \\
\text { range [234] }\end{array}$ & $\begin{array}{c}\text { Elevated in smokers [242]; renal } \\
\text { insufficiency (greater than BNP) [243]. } \\
\text { Lower in obesity [239]. } \\
\text { Not degraded by neprilysin (can be used } \\
\text { to monitor ARNI therapy) [241]. }\end{array}$ \\
\hline Galectin-3 & $\begin{array}{c}\text { At presentation as a } \\
\text { prognostic marker [144] }\end{array}$ & $\begin{array}{l}\text { Levels remain stable over } \\
\text { time [141] }\end{array}$ & $\begin{array}{l}\text { Conflicting evidence for association with } \\
\text { sex, age, DM, and HTN }[244,245]\end{array}$ \\
\hline sST2 & $\begin{array}{l}\text { Serially, as a prognostic } \\
\text { marker }[172,201,246]\end{array}$ & $\begin{array}{l}\text { Levels may remain elevated } \\
\text { (indicating worse prognosis) } \\
\text { or decrease by } 48-72 \mathrm{~h} \text { [247] }\end{array}$ & $\begin{array}{l}\text { Elevated in smoking [248], males, DM } \\
\text { [249], and ALD [250] }\end{array}$ \\
\hline hsCRP & $\begin{array}{l}\text { As a risk-enhancing factor at } \\
\text { screening for patients at } \\
\text { borderline or intermediate } \\
\text { risk of atherosclerotic } \\
\text { CVD [251] }\end{array}$ & $\begin{array}{l}\text { Levels may fluctuate } \\
\text { considerably over time [252], } \\
\text { and statin therapy may } \\
\text { reduce levels [189] }\end{array}$ & $\begin{array}{l}\text { Elevated in smoking }[248,253] \text { and other } \\
\text { inflammatory processes }[254,255]\end{array}$ \\
\hline
\end{tabular}


Table 3. Biomarker recommendations from AHA/ACC and ESC guidelines. Abbreviations: $\mathrm{AHA}=$ American Heart Association; $\mathrm{ACC}=$ American College of Cardiology; ACS = acute coronary syndromes; $\mathrm{BNP}=$ brain natriuretic peptide; $\mathrm{B}-\mathrm{NR}=$ level of evidence $\mathrm{B}$ (non-randomized trials); $\mathrm{B}-\mathrm{R}=$ level of evidence $\mathrm{B}$ (randomized trial); $\mathrm{CK}-\mathrm{MB}=$ myocardial creatine kinase isoenzyme; $\mathrm{COR}=$ class of recommendation; $\mathrm{CVD}=$ cardiovascular disease; $\mathrm{ESC}=$ European Society of Cardiology; $\mathrm{HF}=$ heart failure; h-FABP = heart-type fatty acid-binding protein; hsCRP = high-sensitivity C-reactive protein; hscTn = high-sensitivity cardiac troponin; LOE = level of evidence; NT-proBNP = N-terminal pro-BNP; sLOX-1 = soluble lectin-like oxidized low-density lipoprotein receptor-1; sST2 = soluble suppression of tumorigenesis-2. Classes of recommendation: $\mathrm{I}=$ use is recommended; $\mathrm{II}=$ use is reasonable or should be considered; IIa = use is reasonable; $\mathrm{IIb}=$ use may be reasonable; III = use may be considered. Levels of evidence: $\mathrm{A}=$ data derived from multiple randomized, controlled trials or meta-analyses; $\mathrm{B}=$ data derived from a single randomized clinical trial (B-R) or large non-randomized studies (B-NR); C = consensus opinion of experts, case studies, registries, or standard of care. Left blank if data not listed in guideline.

\begin{tabular}{|c|c|c|c|c|c|c|}
\hline \multirow{2}{*}{ Biomarker } & \multicolumn{3}{|c|}{ AHA/ACC } & \multicolumn{3}{|c|}{ ESC } \\
\hline & Recommendation & COR & LOE & Recommendation & COR & LOE \\
\hline CK-MB & $\begin{array}{l}\text { Not recommended for } \\
\text { diagnosis of ACS [256] }\end{array}$ & III & A & $\begin{array}{l}\text { Not recommended for } \\
\text { diagnosis of ACS [257] }\end{array}$ & III & \\
\hline h-FABP & \multicolumn{3}{|c|}{ Not in guidelines } & $\begin{array}{l}\text { Not recommended for } \\
\text { diagnosis of ACS [257] }\end{array}$ & III & B \\
\hline \multirow[t]{2}{*}{ Troponin } & Diagnosis of ACS [256] & I & A & Diagnosis of ACS [257] & I & B \\
\hline & $\begin{array}{l}\text { Additive risk stratification in } \\
\text { chronic HF (hscTn) [182] }\end{array}$ & $\mathrm{IIlb}$ & B-NR & & & \\
\hline sLOX-1 & \multicolumn{3}{|c|}{ Not in guidelines } & \multicolumn{3}{|c|}{ Not in guidelines } \\
\hline \multirow{5}{*}{$\begin{array}{l}\text { BNP and } \\
\text { NT-proBNP }\end{array}$} & Screening for HF [182] & IIa & B-R & & & \\
\hline & Diagnosis of HF [182] & I & A & Diagnosis of HF [135] & I & B \\
\hline & $\begin{array}{l}\text { Prognosis or disease severity } \\
\text { in chronic HF [182] }\end{array}$ & I & A & & & \\
\hline & Prognosis in ADHF [182] & I & A & & & \\
\hline & $\begin{array}{l}\text { Pre-discharge for } \\
\text { prognosis [182] }\end{array}$ & IIa & B-NR & & & \\
\hline Galectin-3 & $\begin{array}{l}\text { Additive risk stratification in } \\
\text { chronic HF [182] }\end{array}$ & $\mathrm{IIlb}$ & B-NR & \multicolumn{3}{|c|}{ Not in guidelines } \\
\hline sST2 & $\begin{array}{l}\text { Additive risk stratification in } \\
\text { chronic HF [182] }\end{array}$ & $\mathrm{IIb}$ & B-NR & \multicolumn{3}{|c|}{ Not in guidelines } \\
\hline hsCRP & $\begin{array}{l}\text { As a risk enhancing factor to } \\
\text { aid discussion of statin } \\
\text { therapy initiation [258] }\end{array}$ & & & $\begin{array}{l}\text { Not recommended for } \\
\text { risk stratification in CVD } \\
\text { prevention }[259,260]\end{array}$ & III & B \\
\hline
\end{tabular}

\section{Prospective Biomarker Trials}

While biomarkers can be validated in retrospective cohort or clinical trials, the most convincing evidence for the clinical utility of biomarkers in the future will come from randomized controlled trials (RCTs) comparing health outcomes between patients receiving novel biomarker-guided treatment and the standard of care. This applies to diagnostic and prognostic markers, as well as those that may guide ongoing treatment. There are three main designs of RCTs assessing biomarkers: biomarker-stratified designs, enrichment designs, and biomarker strategy designs [2,261].

In biomarker-stratified trials, patients are analyzed by biomarker-defined groups in the context of a given therapy where there is no pre-specified knowledge of a benefit to the biomarker-defined group. Biomarker assessment can either be performed prospectively or 
retrospectively, though the prospective study design has the benefit of ensuring adequate distribution of patients in the treatment arms and is a true representation of biomarkerguided treatment. However, most examples of this design in the cardiovascular sphere are from retrospective analyses, such as in the CORONA trial [262]. CORONA randomized older patients with heart failure who were not clinically felt to require lipid-lowering therapy to either rosuvastatin or a placebo, and the overall results of the study demonstrated no significant improvement in any of the primary outcomes. In secondary analysis of the trial [263], patients with galectin-3 levels lower than $19.0 \mathrm{ng} / \mathrm{mL}$ were shown to have benefitted more from rosuvastatin therapy, identifying a potentially useful subgroup for precision therapy that could not have been predicted prior to the trial.

In contrast, enrichment designs are applied to demonstrate that a biomarker-defined subgroup of patients benefits from a particular therapy and that they are useful when evidence suggests that treatment of patients in a particular population would be beneficial [2] This design was utilized in the GRAVITAS trial, which studied the effect of high-dose clopidogrel in post-PCI patients with high residual platelet reactivity on standard-dose clopidogrel (though no benefit was seen with the higher dose in patients with high residual platelet activity) [264] and in the CANTOS [265] trial, which studied the effect of antibody-blocking interleukin-1 $\beta$ on patients with previous ACS who had higher levels of high-sensitivity CRP, demonstrating a significantly lower rate of recurrent cardiovascular events when compared with a placebo.

Finally, biomarker strategy designs are used to evaluate the value and clinical utility of applying a biomarker in clinical care and to assess the impact it has on management. This is accomplished by randomizing patients either to a biomarker-guided treatment arm or to a control arm where they receive the usual care. Examples of this include the PROTECT trial [266], where NT-proBNP-guided therapy was found to be superior to standard care, the ongoing GUIDE-IT trial [139], where NT-proBNP levels would be used to guide the intensity of the therapy, and in the ongoing SCOT-HEART [267] trial, where CT coronary angiography (as an "imaging biomarker") was being used to stratify the treatment of stable chest pain.

These study designs highlight that biomarkers have significant potential to improve the precision of risk stratification and of treatment directions for patients in the future. While biomarker discovery and validation has, to a large extent, focused on the performance of the biomarker in the general population, moving forward, we expect to see more studies that seek to apply biomarkers to subgroups in the population where traditional risk markers fail to adequately assess risk or diagnose disease. These types of studies lead into the concept of precision medicine and are starting to pave a new path in biomarker development strategies.

The incorporation of biomarkers into trial design and outcome analysis will continue to expand and be refined as our repertoire of biomarkers and our understanding of what they reflect in the underlying patient improves with time.

\section{Conclusions}

The history of biomarkers in cardiovascular disease is wide-ranging, and while it incorporates several markers critical to the practice of cardiology such as troponin and NT-pro-BNP, it also includes several which were found to have limitations which kept them consigned to the benchtop. Whether we will see more inclusion of these markers in the diagnosis of cardiac pathologies in the future remains to be seen. There are still significant areas of unmet need in the cardiovascular biomarker space, including markers for detection of early atherosclerosis that would enable more aggressive risk factor management prior to a cardiac event and better ways to definitively diagnose STEMI from mimicking conditions such as myocarditis and Takotsubo cardiomyopathy, allowing avoidance of unnecessary invasive angiography.

As discussed above, most cardiac biomarker evaluations to this point have been dichotomous. There remains room to improve on this model, with biomarkers classifying 
patients into risk and severity groups and aligning them with individualized treatments. Furthermore, individualized weighting of factors in combined risk models (e.g., clinical findings, laboratory results, and imaging) may become standard practice as our ability to identify biological differences improves with the technology.

Looking to the future, there are exciting opportunities for rapid progress to be made in cardiac biomarker research as we gain more knowledge of individual differences in biology and the consequent personalization of cardiovascular medicine. The field of cardiology would benefit from markers that could inform about more individualized pathologies and responses to treatment, such as markers that identified the degree of vascular damage in a specific patient from hypertension or, conversely, one that showed beneficial changes in response to medical therapy or increases in exercise. Advancements in technology will allow us to better identify biomarkers using unbiased research strategies which allow us to widely survey the human proteome, metabolome, and immunophenotype, identifying markers or signals which have an association with cardiovascular diseases. The addition of a biosignature to the currently used clinical risk profile with imaging measures may significantly improve our ability to diagnose those at substantial risk of cardiovascular disease. Ongoing efforts to design and undertake innovative clinical trials will be necessary to demonstrate the utility of current and future cardiac biomarkers, providing crucial clinical information to allow integration into current practice.

Author Contributions: All authors contributed intellectually to writing the manuscript, and all authors have read and agreed to the published version of the manuscript.

Funding: The authors report the following financial support for the research, authorship, or publication of this article: K.A.K. is supported by an Australian Commonwealth Government Research Training Program Stipend Scholarship; S.T.V. is supported by a University of Sydney Postgraduate Research Scholarship funded by Heart Research Australia; G.A.F. is supported by a National Health and Medical Research Council Practitioner Fellowship (grant number APP11359290), Heart Research Australia, and the New South Wales Office of Health and Medical Research and NSW Pathology (NSW Statewide Biobank).

Conflicts of Interest: G.F. reports personal consulting fees from CSL and grants from Abbott Diagnostic outside the submitted work. In addition, G.F. has a patent in biomarkers and oxidative stress awarded May 2017 in USA (US9638699B2), which was issued to the Northern Sydney Local Health District. L.C. reports consulting fees from Abbott Diagnostics, Siemens Healthineers, Glycardia, and Beckman Coulter, as well as institutional research grants from Abbott Diagnostics, Siemens, and Beckman Coulter outside the submitted work. The other authors have no disclosures.

\section{References}

1. Lloyd-Jones, D.M.; Liu, K.; Tian, L.; Greenland, P. Narrative Review: Assessment of C-Reactive Protein in Risk Prediction for Cardiovascular Disease. Ann. Intern. Med. 2006, 145, 35-42. [CrossRef]

2. Ahmad, T.; Fiuzat, M.; Pencina, M.J.; Geller, N.L.; Zannad, F.; Cleland, J.G.; Snider, J.V.; Blankenberg, S.; Adams, K.F.; Redberg, R.F.; et al. Charting a roadmap for heart failure biomarker studies. JACC Heart Fail 2014, 2, 477-488. [CrossRef] [PubMed]

3. Pletcher, M.J.; Pignone, M. Evaluating the Clinical Utility of a Biomarker. Circulation 2011, 123, 1116-1124. [CrossRef] [PubMed]

4. Grund, B.; Sabin, C. Analysis of biomarker data: Logs, odds ratios, and receiver operating characteristic curves. Curr. Opin. HIV AIDS 2010, 5, 473-479. [CrossRef]

5. Hanley, J.A.; McNeil, B.J. The meaning and use of the area under a receiver operating characteristic (ROC) curve. Radiology 1982, 143, 29-36. [CrossRef] [PubMed]

6. Cook, N.R. Use and Misuse of the Receiver Operating Characteristic Curve in Risk Prediction. Circulation 2007, 115, 928-935. [CrossRef]

7. McGeechan, K.; Macaskill, P.; Irwig, L.; Liew, G.; Wong, T.Y. Assessing New Biomarkers and Predictive Models for Use in Clinical Practice: A Clinician's Guide. Arch. Intern. Med. 2008, 168, 2304-2310. [CrossRef]

8. Hosmer, D.W.; Lemesbow, S. Goodness of fit tests for the multiple logistic regression model. Commun. Stat. Theory Methods 1980, 9, 1043-1069. [CrossRef]

9. Hosmer, D.W.; Hosmer, T.; Le Cessie, S.; Lemeshow, S. A comparison of goodness-of-fit tests for the logistic regression model. Stat. Med. 1997, 16, 965-980. [CrossRef]

10. Crowson, C.S.; Atkinson, E.J.; Therneau, T.M. Assessing calibration of prognostic risk scores. Stat. Methods Med. Res. 2016, 25, 1692-1706. [CrossRef] 
11. Pencina, M.J.; D'Agostino Sr, R.B.; D'Agostino, R.B., Jr.; Vasan, R.S. Evaluating the added predictive ability of a new marker: From area under the ROC curve to reclassification and beyond. Stat. Med. 2008, 27, 157-212. [CrossRef] [PubMed]

12. Kerr, K.F.; McClelland, R.L.; Brown, E.R.; Lumley, T. Evaluating the Incremental Value of New Biomarkers with Integrated Discrimination Improvement. Am. J. Epidemiol. 2011, 174, 364-374. [CrossRef] [PubMed]

13. Toraih, E.A.; Elshazli, R.M.; Hussein, M.H.; Elgaml, A.; Amin, M.; El-Mowafy, M.; El-Mesery, M.; Ellythy, A.; Duchesne, J.; Killackey, M.T.; et al. Association of cardiac biomarkers and comorbidities with increased mortality, severity, and cardiac injury in COVID-19 patients: A meta-regression and decision tree analysis. J. Med. Virol. 2020, 92, 2473-2488. [CrossRef] [PubMed]

14. Danese, E.; Montagnana, M. An historical approach to the diagnostic biomarkers of acute coronary syndrome. Ann. Transl. Med. 2016, 4, 194. [CrossRef] [PubMed]

15. Ladue, J.S.; Wroblewski, F.; Karmen, A. Serum glutamic oxaloacetic transaminase activity in human acute transmural myocardial infarction. Science 1954, 120, 497-499. [CrossRef]

16. Goldberg, D.M.; Winfield, D.A. Diagnostic accuracy of serum enzyme assays for myocardial infarction in a general hospital population. Br. Heart J. 1972, 34, 597-604. [CrossRef]

17. Coodley, E.L. Evaluation of enzyme diagnosis in myocardial infarction. Am. J. Med. Sci. 1968, 256, 300-305. [CrossRef] [PubMed]

18. Karmen, A.; Wroblewski, F.; Ladue, J.S. Transaminase activity in human blood. J. Clin. Investig. 1955, 34, 126-131. [CrossRef] [PubMed]

19. Sobel, B.E.; Shell, W.E. Serum Enzyme Determinations in the Diagnosis and Assessment of Myocardial Infarction. Circulation 1972, 45, 471-482. [CrossRef]

20. Johnston, C.C.; Bolton, E.C. Cardiac enzymes. Ann. Emerg. Med. 1982, 11, 27-35. [CrossRef]

21. Dreyfus, J.C.; Schapira, G.; Resnais, J.; Scebat, L. Serum creatine kinase in the diagnosis of myocardial infarct. Rev. Fr. Etud. Clin. Biol. 1960, 5, 386-387. [PubMed]

22. Sørensen, N.S. Creatine Phosphokinase in the Diagnosis of Myocardial Infarction. Acta Med. Scand. 1963, 174, 725-734. [CrossRef] [PubMed]

23. Duma, R.J.; Siegel, A.L. Serum Creatinine Phosphokinase in Acute Myocardial Infarction: Diagnostic Value. Arch. Intern. Med. 1965, 115, 443-451. [CrossRef] [PubMed]

24. Vincent, W.R.; Rapaport, E. Serum creatine phosphokinase in the diagnosis of acute myocardial infarction. Am. J. Cardiol. 1965, 15, 17-26. [CrossRef]

25. Burger, A.; Richterich, R.; Aebi, H. Die Heterogenitat der Kreatin-Kinase. Biochemistry 1964, 2, 305.

26. Jacobs, H.; Heldt, H.W.; Klingenberg, M. High activity of creatine kinase in mitochondria from muscle and brain and evidence for a separate mitochondrial isoenzyme of creatine kinase. Biochem. Biophys. Res. Commun. 1964, 16, 516-521. [CrossRef]

27. Eppenberger, H.M.; Eppenberger, M.; Richterich, R.; Aebi, H. The ontogeny of creatine kinase isozymes. Dev. Biol. 1964, 10, 1-16. [CrossRef]

28. Konttinen, A.; Somer, H. Determination of serum creatine kinase isoenzymes in myocardial infarction. Am. J. Cardiol. 1972, 29, 817-820. [CrossRef]

29. Grande, P.; Christiansen, C.; Næstoft, J. Creatine kinase isoenzyme MB assay by electrophoresis. Scand. J. Clin. Lab. Investig. 1979, 39, 607-612. [CrossRef]

30. Ljungdahl, L.; Gerhardt, W.; Hofvendahl, S. Serum creatine kinase B subunit activity in diagnosis of acute myocardial infarction. Br. Heart J. 1980, 43, 514-522. [CrossRef]

31. Gerhardt, W.; Waldenström, J.; Hörder, M.; Hofvendahl, S.; Billström, R.; Ljungdahl, R.; Berning, H.; Bagger, P. Creatine kinase and creatine kinase B-subunit activity in serum in cases of suspected myocardial infarction. Clin. Chem. 1982, 28, 277-283. [CrossRef] [PubMed]

32. Roberts, R.; Gowda, K.S.; Ludbrook, P.A.; Sobel, B.E. Specificity of elevated serum MB creatine phosphokinase activity in the diagnosis of acute myocardial infarction. Am. J. Cardiol. 1975, 36, 433-437. [CrossRef]

33. Blomberg, D.J.; Kimber, W.D.; Burke, M.D. Creatine kinase isoenzymes. Predictive value in the early diagnosis of acute myocardial infarction. Am. J. Med. 1975, 59, 464-469. [CrossRef]

34. Puleo, P.R.; Guadagno, P.A.; Roberts, R.; Scheel, M.V.; Marian, A.J.; Churchill, D.; Perryman, M.B. Early diagnosis of acute myocardial infarction based on assay for subforms of creatine kinase-MB. Circulation 1990, 82, 759-764. [CrossRef] [PubMed]

35. Puleo, P.R.; Meyer, D.; Wathen, C.; Tawa, C.B.; Wheeler, S.; Hamburg, R.J.; Ali, N.; Obermueller, S.D.; Triana, F.J.; Zimmerman, J.L.; et al. Use of a Rapid Assay of Subforms of Creatine Kinase MB to Diagnose or Rule Out Acute Myocardial Infarction. N. Engl. J. Med. 1994, 331, 561-566. [CrossRef]

36. Lee, T.H.; Goldman, L. Serum enzyme assays in the diagnosis of acute myocardial infarction. Recommendations based on a quantitative analysis. Ann. Intern. Med. 1986, 105, 221-233. [CrossRef] [PubMed]

37. White, R.D.; Grande, P.; Califf, L.; Palmeri, S.T.; Califf, R.M.; Wagner, G.S. Diagnostic and prognostic significance of minimally elevated creatine kinase-mb in suspected acute myocardial infarction. Am. J. Cardiol. 1985, 55, 1478-1484. [CrossRef]

38. Alpert, J.S.; Thygesen, K.; Antman, E.; Bassand, J.P. Myocardial infarction redefined-a consensus document of The Joint European Society of Cardiology/American College of Cardiology Committee for the redefinition of myocardial infarction. J. Am. Coll. Cardiol. 2000, 36, 959-969. [CrossRef]

39. Ockner, R.K.; Manning, J.A.; Poppenhausen, R.B.; Ho, W.K. A binding protein for fatty acids in cytosol of intestinal mucosa, liver, myocardium, and other tissues. Science 1972, 177, 56. [CrossRef] 
40. Glatz, J.F.C.; van Bilsen, M.; Paulussen, R.J.A.; Veerkamp, J.H.; van Der Vusse, G.J.; Reneman, R.S. Release of fatty acid-binding protein from isolated rat heart subjected to ischemia and reperfusion or to the calcium paradox. Biochim. Et Biophys. Acta (BBA)/Lipids Lipid. Metab. 1988, 961, 148-152. [CrossRef]

41. Tanaka, T.; Hirota, Y.; Sohmiya, K.-I.; Nishimura, S.; Kawamura, K. Serum and urinary human heart fatty acid-binding protein in acute myocardial infarction. Clin. Biochem. 1991, 24, 195-201. [CrossRef]

42. Kleine, A.; Glatz, J.; Nieuwenhoven, F.; Vusse, G. Release of heart fatty acid-binding protein into plasma after acute myocardial infarction in man. Mol. Cell. Biochem. 1992, 116, 155-162. [CrossRef]

43. Seino, Y.; Ogata, K.; Takano, T. Use of a whole blood rapid panel test for heart-type fatty acid-binding protein in patients with acute chest pain: Comparison with rapid troponin T and myoglobin tests. ACC Curr. J. Rev. 2004, 13, 12-13. [CrossRef]

44. McCann, C.J.; Glover, B.M.; Menown, I.B.A.; Moore, M.J.; McEneny, J.; Owens, C.G.; Smith, B.; Sharpe, P.C.; Young, I.S.; Adgey, J.A. Novel biomarkers in early diagnosis of acute myocardial infarction compared with cardiac troponin T. Eur. Heart J. 2008, 29, 2843-2850. [CrossRef]

45. Gururajan, P.; Gurumurthy, P.; Nayar, P.; Srinivasa Nageswara Rao, G.; Babu, S.; Cherian, K.M. Heart Fatty Acid Binding Protein (H-FABP) as a Diagnostic Biomarker in Patients with Acute Coronary Syndrome. Heart Lung Circ. 2010, 19, 660-664. [CrossRef] [PubMed]

46. Wodzig, K.W.; Pelsers, M.M.; van der Vusse, G.J.; Roos, W.; Glatz, J.F. One-step enzyme-linked immunosorbent assay (ELISA) for plasma fatty acid-binding protein. Ann. Clin. Biochem. 1997, 34 Pt 3, 263-268. [CrossRef] [PubMed]

47. Willemsen, R.T.A.; van Severen, E.; Vandervoort, P.M.; Grieten, L.; Buntinx, F.; Glatz, J.F.; Dinant, G.J. Heart-type fatty acid binding protein (H-FABP) in patients in an emergency department setting, suspected of acute coronary syndrome: Optimal cut-off point, diagnostic value and future opportunities in primary care. Eur. J. Gen. Pract. 2015, 21, 156-163. [CrossRef]

48. Body, R.; Burrows, G.; Carley, S.; Lewis, P.S. The Manchester Acute Coronary Syndromes (MACS) decision rule: Validation with a new automated assay for heart-type fatty acid binding protein. Emerg. Med. J. 2015, 32, 769-774. [CrossRef]

49. Bivona, G.; Agnello, L.; Bellia, C.; Lo Sasso, B.; Ciaccio, M. Diagnostic and prognostic value of H-FABP in acute coronary syndrome: Still evidence to bring. Clin. Biochem. 2018, 58, 1-4. [CrossRef]

50. Willemsen, R.T.; Winkens, B.; Kietselaer, B.L.; Smolinska, A.; Buntinx, F.; Glatz, J.F.; Dinant, G.-J. Evaluating possible acute coronary syndrome in primary care: The value of signs, symptoms, and plasma heart-type fatty acid-binding protein (H-FABP). A diagnostic study. BJGP Open 2019, 3, bjgpopen19X101652. [CrossRef]

51. Ebashi, S.; Kodama, A. A new protein factor promoting aggregation of tropomyosin. J. Biochem. 1965, 58, 107-108. [CrossRef] [PubMed]

52. Greaser, M.L.; Gergely, J. Reconstitution of troponin activity from three protein components. J. Biol. Chem. 1971, 246, 4226-4233. [CrossRef]

53. Cummins, B.; Auckland, M.L.; Cummins, P. Cardiac-specific troponin-I radioimmunoassay in the diagnosis of acute myocardial infarction. Am. Heart J. 1987, 113, 1333-1344. [CrossRef]

54. Katus, H.A.; Remppis, A.; Looser, S.; Hallermeier, K.; Scheffold, T.; Kubler, W. Enzyme linked immuno assay of cardiac troponin $\mathrm{T}$ for the detection of acute myocardial infarction in patients. J. Mol. Cell Cardiol. 1989, 21, 1349-1353. [CrossRef]

55. Ravkilde, J.; Hørder, M.; Gerhardt, W.; Ljungdahl, L.; Pettersson, T.; Tryding, N.; Møller, B.H.; Hamfelt, A.; Graven, T.; Åsberg, A.; et al. Diagnostic performance and prognostic value of serum troponin T in suspected acute myocardial infarction. Scand. J. Clin. Lab. Investig. 1993, 53, 677-685. [CrossRef] [PubMed]

56. Ohman, E.M.; Armstrong, P.W.; Christenson, R.H.; Granger, C.B.; Katus, H.A.; Hamm, C.W.; O’Hanesian, M.A.; Wagner, G.S.; Kleiman, N.S.; Harrell, F.E.; et al. Cardiac Troponin T Levels for Risk Stratification in Acute Myocardial Ischemia. N. Engl. J. Med. 1996, 335, 1333-1342. [CrossRef]

57. Hamm, C.W.; Ravkilde, J.; Gerhardt, W.; Jørgensen, P.; Peheim, E.; Ljungdahl, L.; Goldmann, B.; Katus, H.A. The Prognostic Value of Serum Troponin T in Unstable Angina. N. Engl. J. Med. 1992, 327, 146-150. [CrossRef]

58. Collinson, P.; Gerhardt, W.; Katus, H.; Müller-Bardorff, M.; Braun, S.; Schricke, U.; Vogt, W.; Nagel, D.; Zander, M.; Leinberger, R.; et al. Multicentre evaluation of an immunological rapid test for the detection of troponin $\mathrm{T}$ in whole blood samples. Ren. Fail. 1996, 34, 591-598.

59. Hamm, C.W.; Goldmann, B.U.; Heeschen, C.; Kreymann, G.; Berger, J.; Meinertz, T. Emergency room triage of patients with acute chest pain by means of rapid testing for cardiac troponin T or troponin I. N. Engl. J. Med. 1997, 337, 1648-1653. [CrossRef]

60. D'Costa, M.; Fleming, E.; Patterson, M.C. Cardiac Troponin I for the Diagnosis of Acute Myocardial Infarction in the Emergency Department. Am. J. Clin. Pathol. 1997, 108, 550-555. [CrossRef]

61. Antman, E.M.; Tanasijevic, M.J.; Thompson, B.; Schactman, M.; McCabe, C.H.; Cannon, C.P.; Fischer, G.A.; Fung, A.Y.; Thompson, C.; Wybenga, D.; et al. Cardiac-Specific Troponin I Levels to Predict the Risk of Mortality in Patients with Acute Coronary Syndromes. N. Engl. J. Med. 1996, 335, 1342-1349. [CrossRef] [PubMed]

62. Wu, A.H.; Apple, F.S.; Gibler, W.B.; Jesse, R.L.; Warshaw, M.M.; Valdes, R., Jr. National Academy of Clinical Biochemistry Standards of Laboratory Practice: Recommendations for the Use of Cardiac Markers in Coronary Artery Diseases. Clin. Chem. 1999, 45, 1104-1121. [CrossRef] [PubMed]

63. Jaffe, A.S.; Ravkilde, J.; Roberts, R.; Naslund, U.; Apple, F.S.; Galvani, M.; Katus, H. It's time for a change to a troponin standard. Circulation 2000, 102, 1216-1220. [CrossRef] [PubMed] 
64. Apple, F.S.; Jaffe, A.S.; Collinson, P.; Mockel, M.; Ordonez-Llanos, J.; Lindahl, B.; Hollander, J.; Plebani, M.; Than, M.; Chan, M.H.; et al. IFCC educational materials on selected analytical and clinical applications of high sensitivity cardiac troponin assays. Clin. Biochem 2015, 48, 201-203. [CrossRef]

65. Thygesen, K.; Alpert, J.S.; Jaffe, A.S.; Chaitman, B.R.; Bax, J.J.; Morrow, D.A.; White, H.D.; Executive Group on behalf of the Joint European Society of Cardiology / American College of Cardiology / American Heart Association /World Heart Federation Task Force for the Universal Definition of Myocardial, I. Fourth Universal Definition of Myocardial Infarction (2018). Circulation 2018, 138, e618-e651. [CrossRef]

66. Stengaard, C.; Sørensen, J.T.; Ladefoged, S.A.; Lassen, J.F.; Rasmussen, M.B.; Pedersen, C.K.; Ayer, A.; Bøtker, H.E.; Terkelsen, C.J.; Thygesen, K. The potential of optimizing prehospital triage of patients with suspected acute myocardial infarction using high-sensitivity cardiac troponin T and copeptin. Biomarkers 2017, 22, 351-360. [CrossRef]

67. Ishak, M.; Ali, D.; Fokkert, M.J.; Slingerland, R.J.; Tolsma, R.T.; Badings, E.; van der Sluis, A.; van Eenennaam, F.; Mosterd, A.; Ten Berg, J.M.; et al. Fast assessment and management of chest pain patients without ST-elevation in the pre-hospital gateway (FamouS Triage): Ruling out a myocardial infarction at home with the modified HEART score. Eur. Heart J. Acute Cardiovasc. Care 2018, 7, 102-110. [CrossRef]

68. Neumann, J.T.; Twerenbold, R.; Ojeda, F.; Sörensen, N.A.; Chapman, A.R.; Shah, A.S.V.; Anand, A.; Boeddinghaus, J.; Nestelberger T.; Badertscher, P.; et al. Application of High-Sensitivity Troponin in Suspected Myocardial Infarction. N. Engl. J. Med. 2019, 380, 2529-2540. [CrossRef]

69. Chapman, A.R.; Lee, K.K.; McAllister, D.A.; Cullen, L.; Greenslade, J.H.; Parsonage, W.; Worster, A.; Kavsak, P.A.; Blankenberg, S.; Neumann, J.; et al. Association of High-Sensitivity Cardiac Troponin I Concentration with Cardiac Outcomes in Patients with Suspected Acute Coronary Syndrome. JAMA 2017, 318, 1913-1924. [CrossRef]

70. Chapman, A.R.; Fujisawa, T.; Lee, K.K.; Andrews, J.P.; Anand, A.; Sandeman, D.; Ferry, A.V.; Stewart, S.; Marshall, L.; Strachan, F.E.; et al. Novel high-sensitivity cardiac troponin I assay in patients with suspected acute coronary syndrome. Heart 2019, 105, 616-622. [CrossRef]

71. Than, M.P.; Pickering, J.W.; Sandoval, Y.; Shah, A.S.V.; Tsanas, A.; Apple, F.S.; Blankenberg, S.; Cullen, L.; Mueller, C.; Neumann, J.T.; et al. Machine Learning to Predict the Likelihood of Acute Myocardial Infarction. Circulation 2019, 140, 899-909. [CrossRef]

72. Shah, A.S.; Anand, A.; Sandoval, Y.; Lee, K.K.; Smith, S.W.; Adamson, P.D.; Chapman, A.R.; Langdon, T.; Sandeman, D.; Vaswani, A.; et al. High-sensitivity cardiac troponin I at presentation in patients with suspected acute coronary syndrome: A cohort study. Lancet 2015, 386, 2481-2488. [CrossRef]

73. Shah, A.S.V.; Anand, A.; Strachan, F.E.; Ferry, A.V.; Lee, K.K.; Chapman, A.R.; Sandeman, D.; Stables, C.L.; Adamson, P.D.; Andrews, J.P.M.; et al. High-sensitivity troponin in the evaluation of patients with suspected acute coronary syndrome: A stepped-wedge, cluster-randomised controlled trial. Lancet 2018, 392, 919-928. [CrossRef]

74. Anand, A.; Lee, K.K.; Chapman, A.R.; Ferry, A.V.; Adamson, P.D.; Strachan, F.E.; Berry, C.; Findlay, I.; Cruikshank, A.; Reid, A.; et al. High-Sensitivity Cardiac Troponin on Presentation to Rule Out Myocardial Infarction: A Stepped-Wedge Cluster Randomized Controlled Trial. Circulation 2021, 143, 2214-2224. [CrossRef] [PubMed]

75. Apple, F.S.; Ler, R.; Murakami, M.M. Determination of 19 cardiac troponin I and T assay 99th percentile values from a common presumably healthy population. Clin. Chem. 2012, 58, 1574-1581. [CrossRef]

76. Sedaghat-Hamedani, F.; Kayvanpour, E.; Frankenstein, L.; Mereles, D.; Amr, A.; Buss, S.; Keller, A.; Giannitsis, E.; Jensen, K.; Katus, H.A.; et al. Biomarker changes after strenuous exercise can mimic pulmonary embolism and cardiac injury-a metaanalysis of 45 studies. Clin. Chem. 2015, 61, 1246-1255. [CrossRef]

77. Lee, G.; Twerenbold, R.; Tanglay, Y.; Reichlin, T.; Honegger, U.; Wagener, M.; Jaeger, C.; Rubini Gimenez, M.; Hochgruber, T.; Puelacher, C.; et al. Clinical benefit of high-sensitivity cardiac troponin I in the detection of exercise-induced myocardial ischemia. Am. Heart J. 2016, 173, 8-17. [CrossRef] [PubMed]

78. Turer, A.T.; Addo, T.A.; Martin, J.L.; Sabatine, M.S.; Lewis, G.D.; Gerszten, R.E.; Keeley, E.C.; Cigarroa, J.E.; Lange, R.A.; Hillis, L.D.; et al. Myocardial ischemia induced by rapid atrial pacing causes troponin T release detectable by a highly sensitive assay: Insights from a coronary sinus sampling study. J. Am. Coll. Cardiol. 2011, 57, 2398-2405. [CrossRef] [PubMed]

79. McKie, P.M.; Heublein, D.M.; Scott, C.G.; Gantzer, M.L.; Mehta, R.A.; Rodeheffer, R.J.; Redfield, M.M.; Burnett, J.C., Jr.; Jaffe, A.S. Defining high-sensitivity cardiac troponin concentrations in the community. Clin. Chem. 2013, 59, 1099-1107. [CrossRef]

80. Collinson, P.O.; Heung, Y.M.; Gaze, D.; Boa, F.; Senior, R.; Christenson, R.; Apple, F.S. Influence of population selection on the 99th percentile reference value for cardiac troponin assays. Clin. Chem. 2012, 58, 219-225. [CrossRef]

81. Ford, I.; Shah, A.S.; Zhang, R.; McAllister, D.A.; Strachan, F.E.; Caslake, M.; Newby, D.E.; Packard, C.J.; Mills, N.L. High-Sensitivity Cardiac Troponin, Statin Therapy, and Risk of Coronary Heart Disease. J. Am. Coll. Cardiol. 2016, 68, 2719-2728. [CrossRef] [PubMed]

82. Farmakis, D.; Mueller, C.; Apple, F.S. High-sensitivity cardiac troponin assays for cardiovascular risk stratification in the general population. Eur. Heart J. 2020, 41, 4050-4056. [CrossRef] [PubMed]

83. Sawamura, T.; Kume, N.; Aoyama, T.; Moriwaki, H.; Hoshikawa, H.; Aiba, Y.; Tanaka, T.; Miwa, S.; Katsura, Y.; Kita, T.; et al. An endothelial receptor for oxidized low-density lipoprotein. Nature 1997, 386, 73-77. [CrossRef] [PubMed]

84. Navarra, T.; Del Turco, S.; Berti, S.; Basta, G. The lectin-like oxidized low-density lipoprotein receptor-1 and its soluble form: Cardiovascular implications. J. Atheroscler. Thromb. 2010, 17, 317-331. [CrossRef] 
85. Dunn, S.; Vohra, R.S.; Murphy, J.E.; Homer-Vanniasinkam, S.; Walker, J.H.; Ponnambalam, S. The lectin-like oxidized low-densitylipoprotein receptor: A pro-inflammatory factor in vascular disease. Biochem. J. 2008, 409, 349-355. [CrossRef] [PubMed]

86. Shaw, D.J.; Seese, R.; Ponnambalam, S.; Ajjan, R. The role of lectin-like oxidised low-density lipoprotein receptor-1 in vascular pathology. Diab. Vasc. Dis. Res. 2014, 11, 410-418. [CrossRef]

87. Ding, Z.; Liu, S.; Wang, X.; Dai, Y.; Khaidakov, M.; Deng, X.; Fan, Y.; Xiang, D.; Mehta, J.L. LOX-1, mtDNA damage, and NLRP3 inflammasome activation in macrophages: Implications in atherogenesis. Cardiovasc. Res. 2014, 103, 619-628. [CrossRef]

88. Yang, T.C.; Chang, P.Y.; Lu, S.C. L5-LDL from ST-elevation myocardial infarction patients induces IL-1beta production via LOX-1 and NLRP3 inflammasome activation in macrophages. Am. J. Physiol. Heart Circ. Physiol. 2017, 312, H265-H274. [CrossRef]

89. Kattoor, A.J.; Goel, A.; Mehta, J.L. LOX-1: Regulation, Signaling and Its Role in Atherosclerosis. Antioxidants 2019, 8, 218. [CrossRef]

90. Kataoka, H.; Kume, N.; Miyamoto, S.; Minami, M.; Moriwaki, H.; Murase, T.; Sawamura, T.; Masaki, T.; Hashimoto, N.; Kita, T. Expression of lectinlike oxidized low-density lipoprotein receptor-1 in human atherosclerotic lesions. Circulation 1999, 99, 3110-3117. [CrossRef]

91. Li, D.; Patel, A.R.; Klibanov, A.L.; Kramer, C.M.; Ruiz, M.; Kang, B.Y.; Mehta, J.L.; Beller, G.A.; Glover, D.K.; Meyer, C.H. Molecular imaging of atherosclerotic plaques targeted to oxidized LDL receptor LOX-1 by SPECT/CT and magnetic resonance. Circ. Cardiovasc. Imaging 2010, 3, 464-472. [CrossRef]

92. Zhao, X.Q.; Zhang, M.W.; Wang, F.; Zhao, Y.X.; Li, J.J.; Wang, X.P.; Bu, P.L.; Yang, J.M.; Liu, X.L.; Zhang, M.X.; et al. CRP enhances soluble LOX-1 release from macrophages by activating TNF-alpha converting enzyme. J. Lipid Res. 2011, 52, 923-933. [CrossRef]

93. Mitsuoka, H.; Kume, N.; Hayashida, K.; Inui-Hayashiada, A.; Aramaki, Y.; Toyohara, M.; Jinnai, T.; Nishi, E.; Kita, T. Interleukin 18 stimulates release of soluble lectin-like oxidized LDL receptor-1 (sLOX-1). Atherosclerosis 2009, 202, 176-182. [CrossRef] [PubMed]

94. Kume, N.; Mitsuoka, H.; Hayashida, K.; Tanaka, M.; Kominami, G.; Kita, T. Soluble lectin-like oxidized LDL receptor-1 (sLOX-1) as a sensitive and specific biomarker for acute coronary syndrome-comparison with other biomarkers. J. Cardiol. 2010, 56, 159-165. [CrossRef] [PubMed]

95. Hayashida, K.; Kume, N.; Murase, T.; Minami, M.; Nakagawa, D.; Inada, T.; Tanaka, M.; Ueda, A.; Kominami, G.; Kambara, H.; et al. Serum soluble lectin-like oxidized low-density lipoprotein receptor-1 levels are elevated in acute coronary syndrome: A novel marker for early diagnosis. Circulation 2005, 112, 812-818. [CrossRef]

96. Kobayashi, N.; Hata, N.; Kume, N.; Seino, Y.; Inami, T.; Yokoyama, S.; Shinada, T.; Tomita, K.; Kaneshige, T.; Mizuno, K. Soluble lectin-like oxidized low-density lipoprotein receptor-1 as an early biomarker for ST elevation myocardial infarction: Timedependent comparison with other biomarkers: Time-dependent comparison with other biomarkers. Circ. J. 2011, 75, 1433-1439. [CrossRef]

97. Kobayashi, N.; Takano, M.; Hata, N.; Kume, N.; Yamamoto, M.; Yokoyama, S.; Shinada, T.; Tomita, K.; Shirakabe, A.; Otsuka, T.; et al. Soluble lectin-like oxidized LDL receptor-1 (sLOX-1) as a valuable diagnostic marker for rupture of thin-cap fibroatheroma: Verification by optical coherence tomography. Int. J. Cardiol. 2013, 168, 3217-3223. [CrossRef] [PubMed]

98. Balin, M.; Celik, A.; Kobat, M.A. Circulating soluble lectin-like oxidized low-density lipoprotein receptor-1 levels are associated with proximal/middle segment of the LAD lesions in patients with stable coronary artery disease. Clin. Res. Cardiol. 2012, 101, 247-253. [CrossRef]

99. Zhao, Z.W.; Zhu, X.L.; Luo, Y.K.; Lin, C.G.; Chen, L.L. Circulating soluble lectin-like oxidized low-density lipoprotein receptor-1 levels are associated with angiographic coronary lesion complexity in patients with coronary artery disease. Clin. Cardiol. 2011, 34, 172-177. [CrossRef] [PubMed]

100. Li, B.; Zhang, L.H.; Yang, X.G.; Liu, Y.; Liu, X.T.; Ren, Y.G. Postprocedural serum sLOX-1 levels are associated with coronary in-stent restenosis in patients with stable coronary artery disease. Coron. Artery Dis. 2011, 22, 259-263. [CrossRef]

101. Balin, M.; Celik, A.; Kobat, M.A.; Baydas, A. Circulating soluble lectin-like oxidized low-density lipoprotein receptor-1 levels predict percutaneous coronary intervention-related periprocedural myocardial infarction in stable patients undergoing elective native single-vessel PCI. J. Thromb. Thrombolysis 2012, 34, 483-490. [CrossRef]

102. Kume, N.; Mitsuoka, H.; Hayashida, K.; Tanaka, M.; Kita, T. Soluble lectin-like oxidized low-density lipoprotein receptor-1 predicts prognosis after acute coronary syndrome-A pilot study. Circ. J. 2010, 74, 1399-1404. [CrossRef] [PubMed]

103. de Bold, A.J.; Borenstein, H.B.; Veress, A.T.; Sonnenberg, H. A rapid and potent natriuretic response to intravenous injection of atrial myocardial extract in rats. Life Sci. 1981, 28, 89-94. [CrossRef]

104. de Bold, A.J. Atrial natriuretic factor: A hormone produced by the heart. Science 1985, 230, 767-770. [CrossRef]

105. Burnett, J.C., Jr.; Kao, P.C.; Hu, D.C.; Heser, D.W.; Heublein, D.; Granger, J.P.; Opgenorth, T.J.; Reeder, G.S. Atrial natriuretic peptide elevation in congestive heart failure in the human. Science 1986, 231, 1145-1147. [CrossRef]

106. Brandt, R.R.; Wright, R.S.; Redfield, M.M.; Burnett, J.C. Atrial natriuretic peptide in heart failure. J. Am. Coll. Cardiol. 1993, 22, A86-A92. [CrossRef]

107. Sudoh, T.; Kangawa, K.; Minamino, N.; Matsuo, H. A new natriuretic peptide in porcine brain. Nature 1988, 332, 78-81. [CrossRef] [PubMed]

108. Saito, Y.; Nakao, K.; Itoh, H.; Yamada, T.; Mukoyama, M.; Arai, H.; Hosoda, K.; Shirakami, G.; Suga, S.-I.; Minamino, N.; et al. Brain natriuretic peptide is a novel cardiac hormone. Biochem. Biophys. Res. Commun. 1989, 158, 360-368. [CrossRef] 
109. Ogawa, Y.; Nakao, K.; Mukoyama, M.; Shirakami, G.; Itoh, H.; Hosoda, K.; Saito, Y.; Arai, H.; Suga, S.; Jougasaki, M.; et al. Rat brain natriuretic peptide-tissue distribution and molecular form. Endocrinology 1990, 126, 2225-2227. [CrossRef]

110. Kambayashi, Y.; Nakao, K.; Mukoyama, M.; Saito, Y.; Ogawa, Y.; Shiono, S.; Inouye, K.; Yoshida, N.; Imura, H. Isolation and sequence determination of human brain natriuretic peptide in human atrium. FEBS Lett. 1990, 259, 341-345. [CrossRef]

111. Mukoyama, M.; Nakao, K.; Hosoda, K.; Suga, S.; Saito, Y.; Ogawa, Y.; Shirakami, G.; Jougasaki, M.; Obata, K.; Yasue, H. Brain natriuretic peptide as a novel cardiac hormone in humans. Evidence for an exquisite dual natriuretic peptide system, atrial natriuretic peptide and brain natriuretic peptide. J. Clin. Investig. 1991, 87, 1402-1412. [CrossRef] [PubMed]

112. Yasue, H.; Yoshimura, M.; Sumida, H.; Kikuta, K.; Kugiyama, K.; Jougasaki, M.; Ogawa, H.; Okumura, K.; Mukoyama, M.; Nakao, $\mathrm{K}$. Localization and mechanism of secretion of B-type natriuretic peptide in comparison with those of A-type natriuretic peptide in normal subjects and patients with heart failure. Circulation 1994, 90, 195-203. [CrossRef] [PubMed]

113. Cowie, M.R.; Struthers, A.D.; Wood, D.A.; Coats, A.J.; Thompson, S.G.; Poole-Wilson, P.A.; Sutton, G.C. Value of natriuretic peptides in assessment of patients with possible new heart failure in primary care. Lancet 1997, 350, 1349-1353. [CrossRef]

114. Doust, J.A.; Glasziou, P.P.; Pietrzak, E.; Dobson, A.J. A Systematic Review of the Diagnostic Accuracy of Natriuretic Peptides for Heart Failure. Arch. Intern. Med. 2004, 164, 1978-1984. [CrossRef]

115. Jensen, K.T.; Carstens, J.; Ivarsen, P.; Pedersen, E.B. A new, fast and reliable radioimmunoassay of brain natriuretic peptide in human plasma. Reference values in healthy subjects and in patients with different diseases. Scand. J. Clin. Lab. Investig. 1997, 57, 529-540. [CrossRef]

116. Maisel, A.S.; Krishnaswamy, P.; Nowak, R.M.; McCord, J.; Hollander, J.E.; Duc, P.; Omland, T.; Storrow, A.B.; Abraham, W.T.; $\mathrm{Wu}, \mathrm{A} . \mathrm{H}$.; et al. Rapid measurement of B-type natriuretic peptide in the emergency diagnosis of heart failure. N. Engl. J. Med. 2002, 347, 161-167. [CrossRef]

117. Nakamura, M.; Endo, H.; Nasu, M.; Arakawa, N.; Segawa, T.; Hiramori, K. Value of plasma B type natriuretic peptide measurement for heart disease screening in a Japanese population. Heart 2002, 87, 131-135. [CrossRef]

118. McDonagh, T.A.; Robb, S.D.; Murdoch, D.R.; Morton, J.J.; Ford, I.; Morrison, C.E.; Tunstall-Pedoe, H.; McMurray, J.J.; Dargie, H.J Biochemical detection of left-ventricular systolic dysfunction. Lancet 1998, 351, 9-13. [CrossRef]

119. Ng, L.L.; Loke, I.; Davies, J.E.; Khunti, K.; Stone, M.; Abrams, K.R.; Chin, D.T.; Squire, I.B. Identification of previously undiagnosed left ventricular systolic dysfunction: Community screening using natriuretic peptides and electrocardiography. Eur. J. Heart Fail. 2003, 5, 775-782. [CrossRef]

120. Mair, J.; Friedl, W.; Thomas, S.; Puschendorf, B. Natriuretic peptides in assessment of left-ventricular dysfunction. Scand. J. Clin. Lab. Investig. 1999, 59, 132-142. [CrossRef]

121. Hammerer-Lercher, A.; Neubauer, E.; Müller, S.; Pachinger, O.; Puschendorf, B.; Mair, J. Head-to-head comparison of N-terminal pro-brain natriuretic peptide, brain natriuretic peptide and $\mathrm{N}$-terminal pro-atrial natriuretic peptide in diagnosing left ventricular dysfunction. Clin. Chim. Acta 2001, 310, 193-197. [CrossRef]

122. Richards, A.M.; Nicholls, M.G.; Yandle, T.G.; Frampton, C.; Espiner, E.A.; Turner, J.G.; Buttimore, R.C.; Lainchbury, J.G.; Elliott, J.M.; Ikram, H.; et al. Plasma N-terminal pro brain natriuretic peptide and adrenomedullin: New neurohormonal predictors of left ventricular function and prognosis after myocardial infarction. Circulation 1998, 97, 1921-1929. [CrossRef] [PubMed]

123. Januzzi, J.L.; van Kimmenade, R.; Lainchbury, J.; Bayes-Genis, A.; Ordonez-Llanos, J.; Santalo-Bel, M.; Pinto, Y.M.; Richards, M. NT-proBNP testing for diagnosis and short-term prognosis in acute destabilized heart failure: An international pooled analysis of 1256 patients: The International Collaborative of NT-proBNP Study. Eur. Heart J. 2006, 27, 330-337. [CrossRef]

124. Lainchbury, J.G.; Campbell, E.; Frampton, C.M.; Yandle, T.G.; Nicholls, M.G.; Richards, A.M. Brain natriuretic peptide and n-terminal brain natriuretic peptide in the diagnosis of heart failure in patients with acute shortness of breath. J. Am. Coll. Cardiol. 2003, 42, 728-735. [CrossRef]

125. Bayés-Genís, A.; Santaló-Bel, M.; Zapico-Muñiz, E.; López, L.; Cotes, C.; Bellido, J.; Leta, R.; Casan, P.; Ordóñez-Llanos, J N-terminal probrain natriuretic peptide (NT-proBNP) in the emergency diagnosis and in-hospital monitoring of patients with dyspnoea and ventricular dysfunction. Eur. J. Heart Fail. 2004, 6, 301-308. [CrossRef] [PubMed]

126. Chen, A.A.; Wood, M.J.; Krauser, D.G.; Baggish, A.L.; Tung, R.; Anwaruddin, S.; Picard, M.H.; Januzzi, J.L. NT-proBNP levels, echocardiographic findings, and outcomes in breathless patients: Results from the ProBNP Investigation of Dyspnoea in the Emergency Department (PRIDE) echocardiographic substudy. Eur. Heart J. 2006, 27, 839-845. [CrossRef]

127. Richards, A.M.; Doughty, R.; Nicholls, M.G.; MacMahon, S.; Sharpe, N.; Murphy, J.; Espiner, E.A.; Frampton, C.; Yandle, T.G. Plasma N-terminal pro-brain natriuretic peptide and adrenomedullin: Prognostic utility and prediction of benefit from carvedilol in chronic ischemic left ventricular dysfunction. Australia-New Zealand Heart Failure Group. J. Am. Coll. Cardiol. 2001, 37, 1781-1787. [CrossRef]

128. Hartmann, F.; Packer, M.; Coats, A.J.; Fowler, M.B.; Krum, H.; Mohacsi, P.; Rouleau, J.L.; Tendera, M.; Castaigne, A.; Anker, S.D.; et al. Prognostic impact of plasma N-terminal pro-brain natriuretic peptide in severe chronic congestive heart failure: A substudy of the Carvedilol Prospective Randomized Cumulative Survival (COPERNICUS) trial. Circulation 2004, 110, 1780-1786. [CrossRef]

129. Bettencourt, P.; Azevedo, A.; Pimenta, J.; Friões, F.; Ferreira, S.; Ferreira, A. N-terminal-pro-brain natriuretic peptide predicts outcome after hospital discharge in heart failure patients. Circulation 2004, 110, 2168-2174. [CrossRef] 
130. Schou, M.; Gustafsson, F.; Corell, P.; Kistorp, C.N.; Kjaer, A.; Hildebrandt, P.R. The relationship between N-terminal pro-brain natriuretic peptide and risk for hospitalization and mortality is curvilinear in patients with chronic heart failure. Am. Heart $\mathrm{J}$. 2007, 154, 123-129. [CrossRef]

131. Hunt, P.J.; Richards, A.M.; Nicholls, M.G.; Yandle, T.G.; Doughty, R.N.; Espiner, E.A. Immunoreactive amino-terminal pro-brain natriuretic peptide (NT-PROBNP): A new marker of cardiac impairment. Clin. Endocrinol. 1997, 47, 287-296. [CrossRef] [PubMed]

132. Mair, J. Biochemistry of B-type natriuretic peptide-where are we now? Clin. Chem. Lab. Med. 2008, 46, 1507-1514. [CrossRef] [PubMed]

133. Rørth, R.; Jhund, P.S.; Yilmaz, M.B.; Kristensen, S.L.; Welsh, P.; Desai, A.S.; Køber, L.; Prescott, M.F.; Rouleau, J.L.; Solomon, S.D.; et al. Comparison of BNP and NT-proBNP in Patients with Heart Failure and Reduced Ejection Fraction. Circ. Heart Fail. 2020, 13, e006541. [CrossRef]

134. Atherton, J.J.; Sindone, A.; De Pasquale, C.G.; Driscoll, A.; MacDonald, P.S.; Hopper, I.; Kistler, P.M.; Briffa, T.; Wong, J.; Abhayaratna, W.; et al. National Heart Foundation of Australia and Cardiac Society of Australia and New Zealand: Guidelines for the Prevention, Detection, and Management of Heart Failure in Australia 2018. Heart Lung. Circ. 2018, 27, 1123-1208. [CrossRef] [PubMed]

135. McDonagh, T.A.; Metra, M.; Adamo, M.; Gardner, R.S.; Baumbach, A.; Böhm, M.; Burri, H.; Butler, J.; Čelutkienė, J.; Chioncel, O.; et al. 2021 ESC Guidelines for the diagnosis and treatment of acute and chronic heart failure: Developed by the Task Force for the diagnosis and treatment of acute and chronic heart failure of the European Society of Cardiology (ESC) With the special contribution of the Heart Failure Association (HFA) of the ESC. Eur. Heart J. 2021, 42, 3599-3726. [CrossRef]

136. Suthahar, N.; Meems, L.M.G.; Ho, J.E.; de Boer, R.A. Sex-related differences in contemporary biomarkers for heart failure: A review. Eur. J. Heart Fail. 2020, 22, 775-788. [CrossRef]

137. Felker, G.M.; Hasselblad, V.; Hernandez, A.F.; O'Connor, C.M. Biomarker-guided therapy in chronic heart failure: A meta-analysis of randomized controlled trials. Am. Heart J. 2009, 158, 422-430. [CrossRef]

138. Pfisterer, M.; Buser, P.; Rickli, H.; Gutmann, M.; Erne, P.; Rickenbacher, P.; Vuillomenet, A.; Jeker, U.; Dubach, P.; Beer, H.; et al BNP-Guided vs Symptom-Guided Heart Failure Therapy: The Trial of Intensified vs Standard Medical Therapy in Elderly Patients with Congestive Heart Failure (TIME-CHF) Randomized Trial. JAMA 2009, 301, 383-392. [CrossRef]

139. Felker, G.M.; Anstrom, K.J.; Adams, K.F.; Ezekowitz, J.A.; Fiuzat, M.; Houston-Miller, N.; Januzzi, J.L., Jr.; Mark, D.B.; Piña, I.L.; Passmore, G.; et al. Effect of Natriuretic Peptide-Guided Therapy on Hospitalization or Cardiovascular Mortality in High-Risk Patients with Heart Failure and Reduced Ejection Fraction: A Randomized Clinical Trial. JAMA 2017, 318, 713-720. [CrossRef]

140. Sharma, U.C.; Pokharel, S.; van Brakel, T.J.; van Berlo, J.H.; Cleutjens, J.P.; Schroen, B.; Andre, S.; Crijns, H.J.; Gabius, H.J.; Maessen, J.; et al. Galectin-3 marks activated macrophages in failure-prone hypertrophied hearts and contributes to cardiac dysfunction. Circulation 2004, 110, 3121-3128. [CrossRef]

141. de Boer, R.A.; Lok, D.J.; Jaarsma, T.; van der Meer, P.; Voors, A.A.; Hillege, H.L.; van Veldhuisen, D.J. Predictive value of plasma galectin-3 levels in heart failure with reduced and preserved ejection fraction. Ann. Med. 2011, 43, 60-68. [CrossRef]

142. van Kimmenade, R.R.; Januzzi, J.L., Jr.; Ellinor, P.T.; Sharma, U.C.; Bakker, J.A.; Low, A.F.; Martinez, A.; Crijns, H.J.; MacRae, C.A.; Menheere, P.P.; et al. Utility of amino-terminal pro-brain natriuretic peptide, galectin-3, and apelin for the evaluation of patients with acute heart failure. J. Am. Coll. Cardiol. 2006, 48, 1217-1224. [CrossRef] [PubMed]

143. Lok, D.J.; Van Der Meer, P.; de la Porte, P.W.; Lipsic, E.; Van Wijngaarden, J.; Hillege, H.L.; van Veldhuisen, D.J. Prognostic value of galectin-3, a novel marker of fibrosis, in patients with chronic heart failure: Data from the DEAL-HF study. Clin. Res. Cardiol. 2010, 99, 323-328. [CrossRef] [PubMed]

144. Imran, T.F.; Shin, H.J.; Mathenge, N.; Wang, F.; Kim, B.; Joseph, J.; Gaziano, J.M.; Djousse, L. Meta-Analysis of the Usefulness of Plasma Galectin-3 to Predict the Risk of Mortality in Patients with Heart Failure and in the General Population. Am. J. Cardiol 2017, 119, 57-64. [CrossRef] [PubMed]

145. Meijers, W.C.; Januzzi, J.L.; deFilippi, C.; Adourian, A.S.; Shah, S.J.; van Veldhuisen, D.J.; de Boer, R.A. Elevated plasma galectin-3 is associated with near-term rehospitalization in heart failure: A pooled analysis of 3 clinical trials. Am. Heart J. 2014, 167, 853-860.e854. [CrossRef]

146. French, B.; Wang, L.; Ky, B.; Brandimarto, J.; Basuray, A.; Fang, J.C.; Sweitzer, N.K.; Cappola, T.P. Prognostic Value of Galectin-3 for Adverse Outcomes in Chronic Heart Failure. J. Card Fail. 2016, 22, 256-262. [CrossRef]

147. van Vark, L.C.; Lesman-Leegte, I.; Baart, S.J.; Postmus, D.; Pinto, Y.M.; de Boer, R.A.; Asselbergs, F.W.; Wajon, E.; Orsel, J.G.; Boersma, E.; et al. Prognostic Value of Serial Galectin-3 Measurements in Patients with Acute Heart Failure. J. Am. Heart Assoc. 2017, 6, e003700. [CrossRef]

148. Wang, H.; Chen, Q.; Li, Y.; Jing, X.; Liang, T.; Yang, J. Prognostic value of galectin-3 on admission in Chinese patients with heart failure: A prospective observational study. Acta Cardiol. 2017, 72, 188-195. [CrossRef]

149. Yu, X.; Sun, Y.; Zhao, Y.; Zhang, W.; Yang, Z.; Gao, Y.; Cai, H.; Li, Y.; Wang, Q.; Bian, B.; et al. Prognostic value of plasma galectin-3 levels in patients with coronary heart disease and chronic heart failure. Int. Heart J. 2015, 56, 314-318. [CrossRef]

150. Chen, J.-j.; Hao, W.-R.; Chang, K.-C.; Liu, J.-C. LBOS 02-03 the infiltrating macrophage-secreted galectin-3 plays an essential role in cardiac fibrosis and diastolic function in murine pressure-overload model. J. Hypertens. 2016, 34, e549. [CrossRef]

151. Gonzalez, G.E.; Rhaleb, N.E.; D’Ambrosio, M.A.; Nakagawa, P.; Liao, T.D.; Peterson, E.L.; Leung, P.; Dai, X.; Janic, B.; Liu, Y.H.; et al. Cardiac-deleterious role of galectin-3 in chronic angiotensin II-induced hypertension. Am. J. Physiol. Heart Circ. Physiol. 2016, 311, H1287-H1296. [CrossRef] 
152. Hsu, D.K.; Dowling, C.A.; Jeng, K.C.G.; Chen, J.T.; Yang, R.Y.; Liu, F.T. Galectin-3 expression is induced in cirrhotic liver and hepatocellular carcinoma. Int. J. Cancer 1999, 81, 519-526. [CrossRef]

153. Henderson, N.C.; Mackinnon, A.C.; Farnworth, S.L.; Poirier, F.; Russo, F.P.; Iredale, J.P.; Haslett, C.; Simpson, K.J.; Sethi, T Galectin-3 regulates myofibroblast activation and hepatic fibrosis. Proc. Natl. Acad. Sci. USA 2006, 103, 5060-5065. [CrossRef] [PubMed]

154. Nishi, Y.; Sano, H.; Kawashima, T.; Okada, T.; Kuroda, T.; Kikkawa, K.; Kawashima, S.; Tanabe, M.; Goto, T.; Matsuzawa, Y.; et al. Role of Galectin-3 in Human Pulmonary Fibrosis. Allergol. Int. 2007, 56, 57-65. [CrossRef]

155. Ho, J.E.; Liu, C.; Lyass, A.; Courchesne, P.; Pencina, M.J.; Vasan, R.S.; Larson, M.G.; Levy, D. Galectin-3, a Marker of Cardiac Fibrosis, Predicts Incident Heart Failure in the Community. J. Am. Coll. Cardiol. 2012, 60, 1249-1256. [CrossRef] [PubMed]

156. Tominaga, S. A putative protein of a growth specific cDNA from BALB/c-3T3 cells is highly similar to the extracellular portion of mouse interleukin 1 receptor. FEBS Lett. 1989, 258, 301-304. [CrossRef]

157. Pascual-Figal, D.A.; Januzzi, J.L. The Biology of ST2: The International ST2 Consensus Panel. Am. J. Cardiol. 2015, 115, 3B-7B. [CrossRef]

158. Schmitz, J.; Owyang, A.; Oldham, E.; Song, Y.; Murphy, E.; McClanahan, T.K.; Zurawski, G.; Moshrefi, M.; Qin, J.; Li, X.; et al. IL-33, an Interleukin-1-like Cytokine that Signals via the IL-1 Receptor-Related Protein ST2 and Induces T Helper Type 2-Associated Cytokines. Immunity 2005, 23, 479-490. [CrossRef]

159. Kakkar, R.; Hei, H.; Dobner, S.; Lee, R.T. Interleukin 33 as a Mechanically Responsive Cytokine Secreted by Living Cells. J. Biol. Chem. 2012, 287, 6941-6948. [CrossRef]

160. Weinberg, E.O.; Shimpo, M.; De Keulenaer, G.W.; MacGillivray, C.; Tominaga, S.-I.; Solomon, S.D.; Rouleau, J.-L.; Lee, R.T Expression and Regulation of ST2, an Interleukin-1 Receptor Family Member, in Cardiomyocytes and Myocardial Infarction. Circulation 2002, 106, 2961-2966. [CrossRef]

161. Sanada, S.; Hakuno, D.; Higgins, L.J.; Schreiter, E.R.; McKenzie, A.N.J.; Lee, R.T. IL-33 and ST2 comprise a critical biomechanically induced and cardioprotective signaling system. J. Clin. Investig. 2007, 117, 1538-1549. [CrossRef] [PubMed]

162. Seki, K.; Sanada, S.; Kudinova, A.Y.; Steinhauser, M.L.; Handa, V.; Gannon, J.; Lee, R.T. Interleukin-33 prevents apoptosis and improves survival after experimental myocardial infarction through ST2 signaling. Circ. Heart Fail. 2009, 2, 684-691. [CrossRef] [PubMed]

163. Weir, R.A.P.; Miller, A.M.; Murphy, G.E.J.; Clements, S.; Steedman, T.; Connell, J.M.C.; McInnes, I.B.; Dargie, H.J.; McMurray, J.J.V Serum Soluble ST2: A Potential Novel Mediator in Left Ventricular and Infarct Remodeling After Acute Myocardial Infarction. J. Am. Coll. Cardiol. 2010, 55, 243-250. [CrossRef]

164. Shah, R.V.; Chen-Tournoux, A.A.; Picard, M.H.; Van Kimmenade, R.R.J.; Januzzi, J.L. Serum levels of the interleukin-1 receptor family member ST2, cardiac structure and function, and long-term mortality in patients with acute dyspnea. Circ. Heart Fail. 2009, 2, 311-319. [CrossRef] [PubMed]

165. Januzzi, J.L., Jr.; Rehman, S.; Mueller, T.; van Kimmenade, R.R.J.; Lloyd-Jones, D.M. Importance of Biomarkers for Long-Term Mortality Prediction in Acutely Dyspneic Patients. Clin. Chem. 2010, 56, 1814-1821. [CrossRef] [PubMed]

166. de Boer, R.A.; Daniels, L.B.; Maisel, A.S.; Januzzi, J.L., Jr. State of the Art: Newer biomarkers in heart failure. Eur. J. Heart Fail. 2015, 17, 559-569. [CrossRef]

167. Shah, R.V.; Januzzi, J.L. Soluble ST2 and Galectin-3 in Heart Failure. Clin. Lab. Med. 2014, 34, 87-97. [CrossRef]

168. Weinberg, E.O.; Shimpo, M.; Hurwitz, S.; Tominaga, S.I.; Rouleau, J.L.; Lee, R.T. Identification of serum soluble ST2 receptor as a novel heart failure biomarker. Circulation 2003, 107, 721-726. [CrossRef] [PubMed]

169. Bayes-Genis, A.; Zhang, Y.; Ky, B. ST2 and Patient Prognosis in Chronic Heart Failure. Am. J. Cardiol. 2015, 115, 64B-69B. [CrossRef]

170. Aimo, A.; Vergaro, G.; Passino, C.; Ripoli, A.; Ky, B.; Miller, W.L.; Bayes-Genis, A.; Anand, I.; Januzzi, J.L.; Emdin, M. Prognostic Value of Soluble Suppression of Tumorigenicity-2 in Chronic Heart Failure: A Meta-Analysis. JACC Heart Fail. 2017, 5, 280-286. [CrossRef]

171. Januzzi, J.L.; Peacock, W.F.; Maisel, A.S.; Chae, C.U.; Jesse, R.L.; Baggish, A.L.; O’Donoghue, M.; Sakhuja, R.; Chen, A.A.; van Kimmenade, R.R.J.; et al. Measurement of the Interleukin Family Member ST2 in Patients with Acute Dyspnea: Results from the PRIDE (Pro-Brain Natriuretic Peptide Investigation of Dyspnea in the Emergency Department) Study. J. Am. Coll. Cardiol. 2007, 50, 607-613. [CrossRef] [PubMed]

172. Manzano-Fernández, S.; Mueller, T.; Pascual-Figal, D.; Truong, Q.A.; Januzzi, J.L. Usefulness of Soluble Concentrations of Interleukin Family Member ST2 as Predictor of Mortality in Patients with Acutely Decompensated Heart Failure Relative to Left Ventricular Ejection Fraction. Am. J. Cardiol. 2011, 107, 259-267. [CrossRef] [PubMed]

173. Hughes, M.F.; Appelbaum, S.; Havulinna, A.S.; Jagodzinski, A.; Zeller, T.; Kee, F.; Blankenberg, S.; Salomaa, V. ST2 may not be a useful predictor for incident cardiovascular events, heart failure and mortality. Heart 2014, 100, 1715. [CrossRef] [PubMed]

174. Lassus, J.; Gayat, E.; Mueller, C.; Peacock, W.F.; Spinar, J.; Harjola, V.-P.; van Kimmenade, R.; Pathak, A.; Mueller, T.; diSomma, S.; et al. Incremental value of biomarkers to clinical variables for mortality prediction in acutely decompensated heart failure: The Multinational Observational Cohort on Acute Heart Failure (MOCA) study. Int. J. Cardiol. 2013, 168, 2186-2194. [CrossRef]

175. Gaggin, H.K.; Motiwala, S.; Bhardwaj, A.; Parks, K.A.; Januzzi, J.L. Soluble Concentrations of the Interleukin Receptor Family Member ST2 and $\beta$-Blocker Therapy in Chronic Heart Failure. Circ. Heart Fail. 2013, 6, 1206-1213. [CrossRef] 
176. Anand, I.S.; Rector, T.S.; Kuskowski, M.; Snider, J.; Cohn, J.N. Prognostic Value of Soluble ST2 in the Valsartan Heart Failure Trial. Circ. Heart Fail. 2014, 7, 418-426. [CrossRef]

177. Maisel, A.; Xue, Y.; van Veldhuisen, D.J.; Voors, A.A.; Jaarsma, T.; Pang, P.S.; Butler, J.; Pitt, B.; Clopton, P.; de Boer, R.A. Effect of Spironolactone on 30-Day Death and Heart Failure Rehospitalization (from the COACH Study). Am. J. Cardiol. 2014, 114, 737-742. [CrossRef]

178. Rehman, S.U.; Mueller, T.; Januzzi, J.L. Characteristics of the Novel Interleukin Family Biomarker ST2 in Patients with Acute Heart Failure. J. Am. Coll. Cardiol. 2008, 52, 1458-1465. [CrossRef]

179. Bayes-Genis, A.; de Antonio, M.; Vila, J.; Peñafiel, J.; Galán, A.; Barallat, J.; Zamora, E.; Urrutia, A.; Lupón, J. Head-toHead Comparison of 2 Myocardial Fibrosis Biomarkers for Long-Term Heart Failure Risk Stratification. J. Am. Coll. Cardiol. 2014, 63, 158-166. [CrossRef]

180. Gaggin Hanna, K.; Szymonifka, J.; Bhardwaj, A.; Belcher, A.; De Berardinis, B.; Motiwala, S.; Wang Thomas, J.; Januzzi James, L. Head-to-Head Comparison of Serial Soluble ST2, Growth Differentiation Factor-15, and Highly-Sensitive Troponin T Measurements in Patients with Chronic Heart Failure. JACC Heart Fail. 2014, 2, 65-72. [CrossRef]

181. Ahmad, T.; Fiuzat, M.; Neely, B.; Neely Megan, L.; Pen.ncina Michael, J.; Kraus William, E.; Zannad, F.; Whellan David, J.; Donahue Mark, P.; Piña Ileana, L.; et al. Biomarkers of Myocardial Stress and Fibrosis as Predictors of Mode of Death in Patients with Chronic Heart Failure. JACC Heart Fail. 2014, 2, 260-268. [CrossRef]

182. Yancy Clyde, W.; Jessup, M.; Bozkurt, B.; Butler, J.; Casey Donald, E.; Colvin Monica, M.; Drazner Mark, H.; Filippatos Gerasimos, S.; Fonarow Gregg, C.; Givertz Michael, M.; et al. 2017 ACC/AHA/HFSA Focused Update of the 2013 ACCF/AHA Guideline for the Management of Heart Failure. J. Am. Coll. Cardiol. 2017, 70, 776-803. [CrossRef]

183. Ross, R. Atherosclerosis-an inflammatory disease. N. Engl. J. Med. 1999, 340, 115-126. [CrossRef]

184. de Beer, F.C.; Hind, C.R.; Fox, K.M.; Allan, R.M.; Maseri, A.; Pepys, M.B. Measurement of serum C-reactive protein concentration in myocardial ischaemia and infarction. Br. Heart J. 1982, 47, 239-243. [CrossRef]

185. Ridker, P.M.; Cushman, M.; Stampfer, M.J.; Tracy, R.P.; Hennekens, C.H. Inflammation, Aspirin, and the Risk of Cardiovascular Disease in Apparently Healthy Men. N. Engl. J. Med. 1997, 336, 973-979. [CrossRef]

186. Ridker, P.M.; Hennekens, C.H.; Buring, J.E.; Rifai, N. C-Reactive Protein and Other Markers of Inflammation in the Prediction of Cardiovascular Disease in Women. N. Engl. J. Med. 2000, 342, 836-843. [CrossRef] [PubMed]

187. Koenig, W.; Sund, M.; Fröhlich, M.; Fischer, H.-G.; Löwel, H.; Döring, A.; Hutchinson, W.L.; Pepys, M.B. C-Reactive Protein, a Sensitive Marker of Inflammation, Predicts Future Risk of Coronary Heart Disease in Initially Healthy Middle-Aged Men. Circulation 1999, 99, 237-242. [CrossRef] [PubMed]

188. Rost, N.S.; Wolf, P.A.; Kase, C.S.; Kelly-Hayes, M.; Silbershatz, H.; Massaro, J.M.; D'Agostino, R.B.; Franzblau, C.; Wilson, P.W.F. Plasma Concentration of C-Reactive Protein and Risk of Ischemic Stroke and Transient Ischemic Attack. Stroke 2001, 32, 2575-2579. [CrossRef]

189. Ridker, P.M.; Danielson, E.; Fonseca, F.A.H.; Genest, J.; Antonio, M.; Gotto, J.; Kastelein, J.J.P.; Koenig, W.; Libby, P.; Lorenzatti, A.J.; et al. Rosuvastatin to Prevent Vascular Events in Men and Women with Elevated C-Reactive Protein. N. Engl. J. Med. 2008, 359, 2195-2207. [CrossRef] [PubMed]

190. Ward, N.C.; Watts, G.F.; Eckel, R.H. Statin Toxicity. Circ. Res. 2019, 124, 328-350. [CrossRef]

191. Buhaescu, I.; Izzedine, H. Mevalonate pathway: A review of clinical and therapeutical implications. Clin. Biochem. 2007, 40, 575-584. [CrossRef] [PubMed]

192. Pearson, T.A.; Mensah, G.A.; Alexander, R.W.; Anderson, J.L.; Cannon, R.O., 3rd; Criqui, M.; Fadl, Y.Y.; Fortmann, S.P.; Hong, Y.; Myers, G.L.; et al. Markers of inflammation and cardiovascular disease: Application to clinical and public health practice: A statement for healthcare professionals from the Centers for Disease Control and Prevention and the American Heart Association. Circulation 2003, 107, 499-511. [CrossRef] [PubMed]

193. Roberts, W.L. CDC/AHA Workshop on Markers of Inflammation and Cardiovascular Disease: Application to Clinical and Public Health Practice: Laboratory tests available to assess inflammation-performance and standardization: A background paper. Circulation 2004, 110, e572-e576. [CrossRef]

194. Danesh, J.; Collins, R.; Appleby, P.; Peto, R. Association of Fibrinogen, C-reactive Protein, Albumin, or Leukocyte Count with Coronary Heart DiseaseMeta-analyses of Prospective Studies. JAMA 1998, 279, 1477-1482. [CrossRef] [PubMed]

195. Danesh, J.; Whincup, P.; Walker, M.; Lennon, L.; Thomson, A.; Appleby, P.; Gallimore, J.R.; Pepys, M.B. Low grade inflammation and coronary heart disease: Prospective study and updated meta-analyses. BMJ 2000, 321, 199-204. [CrossRef]

196. Koenig, W.; Löwel, H.; Baumert, J.; Meisinger, C. C-Reactive Protein Modulates Risk Prediction Based on the Framingham Score. Circulation 2004, 109, 1349-1353. [CrossRef]

197. Ridker, P.M.; Rifai, N.; Rose, L.; Buring, J.E.; Cook, N.R. Comparison of C-Reactive Protein and Low-Density Lipoprotein Cholesterol Levels in the Prediction of First Cardiovascular Events. N. Engl. J. Med. 2002, 347, 1557-1565. [CrossRef]

198. Wright, S.P.; Doughty, R.N.; Pearl, A.; Gamble, G.D.; Whalley, G.A.; Walsh, H.J.; Gordon, G.; Bagg, W.; Oxenham, H.; Yandle, T.; et al. Plasma amino-terminal pro-brain natriuretic peptide and accuracy of heart-failure diagnosis in primary care: A randomized, controlled trial. J. Am. Coll. Cardiol. 2003, 42, 1793-1800. [CrossRef]

199. Januzzi, J.L.; Camargo, C.A.; Anwaruddin, S.; Baggish, A.L.; Chen, A.A.; Krauser, D.G.; Tung, R.; Cameron, R.; Nagurney, J.T.; Chae, C.U.; et al. The N-terminal Pro-BNP Investigation of Dyspnea in the Emergency department (PRIDE) study. Am. J. Cardiol. 2005, 95, 948-954. [CrossRef] 
200. Dieplinger, B.; Januzzi, J.L.; Steinmair, M.; Gabriel, C.; Poelz, W.; Haltmayer, M.; Mueller, T. Analytical and clinical evaluation of a novel high-sensitivity assay for measurement of soluble ST2 in human plasma-The Presage ${ }^{\mathrm{TM}} \mathrm{ST} 2$ assay. Clin. Chim. Acta 2009, 409, 33-40. [CrossRef]

201. Januzzi, J.L.; Mebazaa, A.; Di Somma, S. ST2 and Prognosis in Acutely Decompensated Heart Failure: The International ST2 Consensus Panel. Am. J. Cardiol. 2015, 115, 26B-31B. [CrossRef] [PubMed]

202. Maisel, A.S.; Di Somma, S. Do we need another heart failure biomarker: Focus on soluble suppression of tumorigenicity 2 (sST2). Eur. Heart J. 2016, 38, 2325-2333. [CrossRef] [PubMed]

203. Laaksonen, D.E.; Niskanen, L.; Nyyssönen, K.; Punnonen, K.; Tuomainen, T.P.; Salonen, J.T. C-reactive protein in the prediction of cardiovascular and overall mortality in middle-aged men: A population-based cohort study. Eur. Heart J. 2005, 26, 1783-1789. [CrossRef]

204. Cabaniss, C.D. Creatine Kinase. In Clinical Methods: The History, Physical, and Laboratory Examinations; Walker, H.K., Hall, W.D., Hurst, J.W., Eds.; Butterworth Publishers; A Division of Reed Publishing: Boston, MA, USA, 1990.

205. Kiely, P.D.W.; Bruckner, F.E.; Nisbet, J.A.; Daghir, A. Serum skeletal troponin I in inflammatory muscle disease: Relation to creatine kinase, CKMB and cardiac troponin I. Ann. Rheum. Dis. 2000, 59, 750. [CrossRef]

206. Siegel, A.J.; Silverman, L.M.; Evans, W.J. Elevated skeletal muscle creatine kinase MB isoenzyme levels in marathon runners. JAMA 1983, 250, 2835-2837. [CrossRef] [PubMed]

207. Ay, H.; Arsava, E.M.; Sarıbaş, O. Creatine Kinase-MB Elevation After Stroke Is Not Cardiac in Origin. Stroke 2002, 33, 286-289. [CrossRef]

208. Ruppert, M.; Van Hee, R. Creatinine-kinase-MB determination in non-cardiac trauma: Its difference with cardiac infarction and its restricted use in trauma situations. Eur. J. Emerg. Med. 2001, 8, 177-179. [CrossRef] [PubMed]

209. Jaffe, A.S.; Ritter, C.; Meltzer, V.; Harter, H.; Roberts, R. Unmasking artifactual increases in creatine kinase isoenzymes in patients with renal failure. J. Lab. Clin. Med. 1984, 104, 193-202.

210. Medeiros, L.J.; Schotte, D.; Gerson, B. Reliability and significance of increased creatine kinase MB isoenzyme in the serum of uremic patients. Am. J. Clin Pathol. 1987, 87, 103-108. [CrossRef]

211. Apple, F.S.; Quist, H.E.; Doyle, P.J.; Otto, A.P.; Murakami, M.M. Plasma 99th percentile reference limits for cardiac troponin and creatine kinase MB mass for use with European Society of Cardiology/American College of Cardiology consensus recommendations. Clin. Chem. 2003, 49, 1331-1336. [CrossRef]

212. Lenke, L.G.; Bridwell, K.H.; Jaffe, A.S. Increase in creatine kinase MB isoenzyme levels after spinal surgery. J Spinal Disord. 1994, 7, 70-76. [CrossRef] [PubMed]

213. Shirakabe, A.; Kobayashi, N.; Hata, N.; Shinada, T.; Tomita, K.; Tsurumi, M.; Okazaki, H.; Matsushita, M.; Yamamoto, Y.; Yokoyama, S.; et al. The serum heart-type fatty acid-binding protein (HFABP) levels can be used to detect the presence of acute kidney injury on admission in patients admitted to the non-surgical intensive care unit. BMC Cardiovasc. Disord. 2016, 16, 174. [CrossRef] [PubMed]

214. Langer, M.; Forkmann, M.; Richter, U.; Tausche, A.-K.; Sveric, K.; Christoph, M.; Ibrahim, K.; Günther, M.; Kolschmann, S.; Boscheri, A.; et al. Heart-type fatty acid-binding protein and myocardial creatine kinase enable rapid risk stratification in normotensive patients with pulmonary embolism. J. Crit. Care 2016, 35, 174-179. [CrossRef]

215. Wunderlich, M.T.; Hanhoff, T.; Goertler, M.; Spener, F.; Glatz, J.F.C.; Wallesch, C.W.; Pelsers, M.M.A.L. Release of brain-type and heart-type fatty acid-binding proteins in serum after acute ischaemic stroke. J. Neurol. 2005, 252, 718-724. [CrossRef] [PubMed]

216. Zhang, Z.-C.; Dai, H.-W.; Yu, Y.-H.; Yang, J.-D.; Hu, C.-B. Usefulness of heart-type fatty acid-binding protein in patients with severe sepsis. J. Crit. Care 2012, 27, 415.e413-415.e418. [CrossRef] [PubMed]

217. Hoffmann, U.; Espeter, F.; Weiß, C.; Ahmad-Nejad, P.; Lang, S.; Brueckmann, M.; Akin, I.; Neumaier, M.; Borggrefe, M.; Behnes, $\mathrm{M}$. Ischemic biomarker heart-type fatty acid binding protein (hFABP) in acute heart failure-Diagnostic and prognostic insights compared to NT-proBNP and troponin I. BMC Cardiovasc. Disord. 2015, 15, 50. [CrossRef] [PubMed]

218. Başar, O.; Akbal, E.; Köklü, S.; Tuna, Y.; Koçak, E.; Başar, N.; Tok, D.; Erbiş, H.; Senes, M. Increased H-FABP concentrations in nonalcoholic fatty liver disease. Possible marker for subclinical myocardial damage and subclinical atherosclerosis. Herz 2013, 38, 417-422. [CrossRef] [PubMed]

219. Aslani, M.R.; Ghobadi, H.; Sarikhani, K.; Hosseininia, S.; Sadeghieh-Ahari, S. Comparison of Serum Heart-Type Fatty Acid Binding Protein Levels in Stable Chronic Obstructive Pulmonary Disease and Healthy Subjects. Tanaffos 2020, 19, $208-215$.

220. Newby, L.K.; Goldmann, B.U.; Ohman, E.M. Troponin: An important prognostic marker and risk-stratification tool in non-STsegment elevation acute coronary syndromes. J. Am. Coll. Cardiol. 2003, 41, S31-S36. [CrossRef]

221. Lewandrowski, K.; Chen, A.; Januzzi, J. Cardiac Markers for Myocardial Infarction: A Brief Review. Pathol. Patterns Rev. 2002, 118, S93-S99. [CrossRef]

222. Ammann, P.; Fehr, T.; Minder, E.I.; Günter, C.; Bertel, O. Elevation of troponin I in sepsis and septic shock. Intensive Care Med. 2001, 27, 965-969. [CrossRef]

223. Lim, W.; Qushmaq, I.; Devereaux, P.J.; Heels-Ansdell, D.; Lauzier, F.; Ismaila, A.S.; Crowther, M.A.; Cook, D.J. Elevated cardiac troponin measurements in critically ill patients. Arch. Intern. Med. 2006, 166, 2446-2454. [CrossRef]

224. Hamwi, S.M.; Sharma, A.K.; Weissman, N.J.; Goldstein, S.A.; Apple, S.; Caños, D.A.; Pinnow, E.E.; Lindsay, J. Troponin-I elevation in patients with increased left ventricular mass. Am. J. Cardiol. 2003, 92, 88-90. [CrossRef] 
225. Wang, C.H.; Kuo, L.T.; Hung, M.J.; Cherng, W.J. Coronary vasospasm as a possible cause of elevated cardiac troponin I in patients with acute coronary syndrome and insignificant coronary artery disease. Am. Heart J. 2002, 144, 275-281. [CrossRef] [PubMed]

226. Troøyen, M.; Indredavik, B.; Rossvoll, O.; Slørdahl, S.A. Myocardial injury in acute stroke assessed by troponin I. Tidsskr Nor Laegeforen 2001, 121, 421-425. [PubMed]

227. Hijazi, Z.; Wallentin, L.; Siegbahn, A.; Andersson, U.; Alexander, J.H.; Atar, D.; Gersh, B.J.; Hanna, M.; Harjola, V.P.; Horowitz, J.D.; et al. High-sensitivity troponin $\mathrm{T}$ and risk stratification in patients with atrial fibrillation during treatment with apixaban or warfarin. J. Am. Coll. Cardiol. 2014, 63, 52-61. [CrossRef]

228. Horwich, T.B.; Patel, J.; MacLellan, W.R.; Fonarow, G.C. Cardiac troponin I is associated with impaired hemodynamics, progressive left ventricular dysfunction, and increased mortality rates in advanced heart failure. Circulation 2003, 108, 833-838. [CrossRef] [PubMed]

229. Smith, S.C.; Ladenson, J.H.; Mason, J.W.; Jaffe, A.S. Elevations of cardiac troponin I associated with myocarditis. Experimental and clinical correlates. Circulation 1997, 95, 163-168. [CrossRef]

230. Hassan, H.C.; Howlin, K.; Jefferys, A.; Spicer, S.T.; Aravindan, A.N.; Suryanarayanan, G.; Hall, B.M.; Cleland, B.D.; Wong, J.K.; Suranyi, M.G.; et al. High-sensitivity troponin as a predictor of cardiac events and mortality in the stable dialysis population. Clin. Chem. 2014, 60, 389-398. [CrossRef] [PubMed]

231. Rubin, J.; Matsushita, K.; Lazo, M.; Ballantyne, C.M.; Nambi, V.; Hoogeveen, R.; Sharrett, A.R.; Blumenthal, R.S.; Coresh, J.; Selvin, E. Determinants of minimal elevation in high-sensitivity cardiac troponin $\mathrm{T}$ in the general population. Clin. Biochem. 2016, 49, 657-662. [CrossRef]

232. Takanabe-Mori, R.; Ono, K.; Wada, H.; Takaya, T.; Ura, S.; Yamakage, H.; Satoh-Asahara, N.; Shimatsu, A.; Takahashi, Y.; Fujita, M.; et al. Lectin-like oxidized low-density lipoprotein receptor-1 plays an important role in vascular inflammation in current smokers. J. Atheroscler Thromb. 2013, 20, 585-590. [CrossRef] [PubMed]

233. Ledwidge, M.; Gallagher, J.; Conlon, C.; Tallon, E.; O'Connell, E.; Dawkins, I.; Watson, C.; O’Hanlon, R.; Bermingham, M.; Patle, A.; et al. Natriuretic Peptide-Based Screening and Collaborative Care for Heart Failure: The STOP-HF Randomized Trial. JAMA 2013, 310, 66-74. [CrossRef]

234. Troughton, R.W.; Mark Richards, A.; Yandle, T.G.; Frampton, C.M.; Gary Nicholls, M. The effects of medications on circulating levels of cardiac natriuretic peptides. Ann. Med. 2007, 39, 242-260. [CrossRef]

235. Latini, R.; Masson, S.; Anand, I.; Judd, D.; Maggioni, A.P.; Chiang, Y.-T.; Bevilacqua, M.; Salio, M.; Cardano, P.; Dunselman, P.H.J.M.; et al. Effects of Valsartan on Circulating Brain Natriuretic Peptide and Norepinephrine in Symptomatic Chronic Heart Failure. Circulation 2002, 106, 2454-2458. [CrossRef] [PubMed]

236. Kamimura, D.; Cain, L.R.; Mentz, R.J.; White, W.B.; Blaha, M.J.; DeFilippis, A.P.; Fox, E.R.; Rodriguez, C.J.; Keith, R.J.; Benjamin, E.J.; et al. Cigarette Smoking and Incident Heart Failure. Circulation 2018, 137, 2572-2582. [CrossRef] [PubMed]

237. Cataliotti, A.; Malatino, L.S.; Jougasaki, M.; Zoccali, C.; Castellino, P.; Giacone, G.; Bellanuova, I.; Tripepi, R.; Seminara, G.; Parlongo, S.; et al. Circulating natriuretic peptide concentrations in patients with end-stage renal disease: Role of brain natriuretic peptide as a biomarker for ventricular remodeling. Mayo Clin. Proc. 2001, 76, 1111-1119. [CrossRef]

238. McCullough, P.A.; Duc, P.; Omland, T.; McCord, J.; Nowak, R.M.; Hollander, J.E.; Herrmann, H.C.; Steg, P.G.; Westheim, A.; Knudsen, C.W.; et al. B-type natriuretic peptide and renal function in the diagnosis of heart failure: An analysis from the Breathing Not Properly Multinational Study. Am. J. Kidney Dis. 2003, 41, 571-579. [CrossRef]

239. Das, S.R.; Drazner, M.H.; Dries, D.L.; Vega, G.L.; Stanek, H.G.; Abdullah, S.M.; Canham, R.M.; Chung, A.K.; Leonard, D.; Wians, F.H., Jr.; et al. Impact of body mass and body composition on circulating levels of natriuretic peptides: Results from the Dallas Heart Study. Circulation 2005, 112, 2163-2168. [CrossRef]

240. Mehra, M.R.; Uber, P.A.; Park, M.H.; Scott, R.L.; Ventura, H.O.; Harris, B.C.; Frohlich, E.D. Obesity and suppressed B-type natriuretic peptide levels in heart failure. J. Am. Coll Cardiol. 2004, 43, 1590-1595. [CrossRef]

241. Packer, M.; McMurray, J.J.V.; Desai, A.S.; Gong, J.; Lefkowitz, M.P.; Rizkala, A.R.; Rouleau, J.L.; Shi, V.C.; Solomon, S.D.; Swedberg, K.; et al. Angiotensin Receptor Neprilysin Inhibition Compared with Enalapril on the Risk of Clinical Progression in Surviving Patients with Heart Failure. Circulation 2015, 131, 54-61. [CrossRef]

242. Otsuka, T.; Kawada, T.; Seino, Y.; Ibuki, C.; Katsumata, M.; Kodani, E. Relation of smoking status to serum levels of N-terminal pro-brain natriuretic peptide in middle-aged men without overt cardiovascular disease. Am. J. Cardiol. 2010, 106, 1456-1460. [CrossRef] [PubMed]

243. Anwaruddin, S.; Lloyd-Jones, D.M.; Baggish, A.; Chen, A.; Krauser, D.; Tung, R.; Chae, C.; Januzzi, J.L., Jr. Renal function, congestive heart failure, and amino-terminal pro-brain natriuretic peptide measurement: Results from the ProBNP Investigation of Dyspnea in the Emergency Department (PRIDE) Study. J. Am. Coll. Cardiol. 2006, 47, 91-97. [CrossRef] [PubMed]

244. de Boer, R.A.; van Veldhuisen, D.J.; Gansevoort, R.T.; Muller Kobold, A.C.; van Gilst, W.H.; Hillege, H.L.; Bakker, S.J.L.; van der Harst, P. The fibrosis marker galectin-3 and outcome in the general population. J. Intern. Med. 2012, 272, 55-64. [CrossRef] [PubMed]

245. Shah, R.V.; Chen-Tournoux, A.A.; Picard, M.H.; van Kimmenade, R.R.J.; Januzzi, J.L. Galectin-3, cardiac structure and function, and long-term mortality in patients with acutely decompensated heart failure. Eur. J. Heart Fail. 2010, 12, 826-832. [CrossRef] [PubMed] 
246. Manzano-Fernández, S.; Januzzi, J.L.; Pastor-Pérez, F.J.; Bonaque-González, J.C.; Boronat-Garcia, M.; Pascual-Figal, D.A.; Montalban-Larrea, S.; Navarro-Peñalver, M.; Andreu-Cayuelas, J.M.; Valdés, M. Serial monitoring of soluble interleukin family member ST2 in patients with acutely decompensated heart failure. Cardiology 2012, 122, 158-166. [CrossRef] [PubMed]

247. Tang, W.H.W.; Wu, Y.; Grodin, J.L.; Hsu, A.P.; Hernandez, A.F.; Butler, J.; Metra, M.; Voors, A.A.; Felker, G.M.; Troughton, R.W.; et al. Prognostic Value of Baseline and Changes in Circulating Soluble ST2 Levels and the Effects of Nesiritide in Acute Decompensated Heart Failure. JACC Heart Fail. 2016, 4, 68-77. [CrossRef]

248. Gottdiener, J.S.; Buzkova, P.; Kahn, P.A.; DeFilippi, C.; Shah, S.; Barasch, E.; Kizer, J.R.; Psaty, B.; Gardin, J.M. Relation of Cigarette Smoking and Heart Failure in Adults $\geq 65$ Years of Age (From the Cardiovascular Health Study). Am. J. Cardiol. 2022; in press. [CrossRef]

249. Filali, Y.; Kesäniemi, Y.A.; Ukkola, O. Soluble ST2, a biomarker of fibrosis, is associated with multiple risk factors, chronic diseases and total mortality in the OPERA study. Scand. J. Clin. Lab. Investig. 2021, 81, 324-331. [CrossRef]

250. Sun, Z.; Chang, B.; Huang, A.; Hao, S.; Gao, M.; Sun, Y.; Shi, M.; Jin, L.; Zhang, W.; Zhao, J.; et al. Plasma levels of soluble ST2, but not IL-33, correlate with the severity of alcoholic liver disease. J. Cell Mol. Med. 2019, 23, 887-897. [CrossRef]

251. Arnett, D.K.; Blumenthal, R.S.; Albert, M.A.; Buroker, A.B.; Goldberger, Z.D.; Hahn, E.J.; Himmelfarb, C.D.; Khera, A.; Lloyd-Jones, D.; McEvoy, J.W.; et al. 2019 ACC/AHA Guideline on the Primary Prevention of Cardiovascular Disease: Executive Summary: A Report of the American College of Cardiology/American Heart Association Task Force on Clinical Practice Guidelines. Circulation 2019, 140, e563-e595. [CrossRef]

252. Bogaty, P.; Brophy, J.M.; Boyer, L.; Simard, S.; Joseph, L.; Bertrand, F.; Dagenais, G.R. Fluctuating inflammatory markers in patients with stable ischemic heart disease. Arch. Intern. Med. 2005, 165, 221-226. [CrossRef] [PubMed]

253. Kianoush, S.; Yakoob, M.Y.; Al-Rifai, M.; DeFilippis, A.P.; Bittencourt, M.S.; Duncan, B.B.; Bensenor, I.M.; Bhatnagar, A.; Lotufo, P.A.; Blaha, M.J. Associations of Cigarette Smoking with Subclinical Inflammation and Atherosclerosis: ELSA-Brasil (The Brazilian Longitudinal Study of Adult Health). J. Am. Heart Assoc. 2017, 6, e005088. [CrossRef] [PubMed]

254. Gabay, C.; Kushner, I. Acute-Phase Proteins and Other Systemic Responses to Inflammation. N. Engl. J. Med. 1999, 340, 448-454. [CrossRef] [PubMed]

255. Kushner, I.; Samols, D.; Magrey, M. A unifying biologic explanation for "high-sensitivity" C-reactive protein and "low-grade" inflammation. Arthritis Care Res. 2010, 62, 442-446. [CrossRef]

256. Amsterdam, E.A.; Wenger, N.K.; Brindis, R.G.; Casey, D.E.; Ganiats, T.G.; Holmes, D.R.; Jaffe, A.S.; Jneid, H.; Kelly, R.F.; Kontos, M.C.; et al. 2014 AHA/ACC guideline for the management of patients with non ST-elevation acute coronary syndromes. J. Am. Coll. Cardiol. 2014, 64, e139-e228. [CrossRef]

257. Collet, J.-P.; Thiele, H.; Barbato, E.; Barthélémy, O.; Bauersachs, J.; Bhatt, D.L.; Dendale, P.; Dorobantu, M.; Edvardsen, T.; Folliguet, T.; et al. 2020 ESC Guidelines for the management of acute coronary syndromes in patients presenting without persistent ST-segment elevation: The Task Force for the management of acute coronary syndromes in patients presenting without persistent ST-segment elevation of the European Society of Cardiology (ESC). Eur. Heart J. 2020, 42, 1289-1367. [CrossRef]

258. Grundy, S.M.; Stone, N.J.; Bailey, A.L.; Beam, C.; Birtcher, K.K.; Blumenthal, R.S.; Braun, L.T.; Ferranti, S.D.; Faiella-Tommasino, J.; Forman, D.E.; et al. 2018 AHA/ACC/AACVPR/AAPA/ABC/ACPM/ADA/AGS/APhA/ASPC/NLA/PCNA Guideline on the Management of Blood Cholesterol: A Report of the American College of Cardiology/American Heart Association Task Force on Clinical Practice Guidelines. Circulation 2019, 139, e1082-e1143. [CrossRef]

259. Visseren, F.L.J.; Mach, F.; Smulders, Y.M.; Carballo, D.; Koskinas, K.C.; Bäck, M.; Benetos, A.; Biffi, A.; Boavida, J.-M.; Capodanno, D.; et al. 2021 ESC Guidelines on cardiovascular disease prevention in clinical practice: Developed by the Task Force for cardiovascular disease prevention in clinical practice with representatives of the European Society of Cardiology and 12 medical societies With the special contribution of the European Association of Preventive Cardiology (EAPC). Eur. Heart J. 2021, 42, 3227-3337. [CrossRef]

260. Knuuti, J.; Wijns, W.; Saraste, A.; Capodanno, D.; Barbato, E.; Funck-Brentano, C.; Prescott, E.; Storey, R.F.; Deaton, C.; Cuisset, T.; et al. 2019 ESC Guidelines for the diagnosis and management of chronic coronary syndromes: The Task Force for the diagnosis and management of chronic coronary syndromes of the European Society of Cardiology (ESC). Eur. Heart J. 2019, 41, 407-477. [CrossRef]

261. Freidlin, B.; McShane, L.M.; Korn, E.L. Randomized clinical trials with biomarkers: Design issues. J. Natl. Cancer Inst. 2010, 102, 152-160. [CrossRef]

262. Kjekshus, J.; Apetrei, E.; Barrios, V.; Böhm, M.; Cleland, J.G.; Cornel, J.H.; Dunselman, P.; Fonseca, C.; Goudev, A.; Grande, P.; et al. Rosuvastatin in older patients with systolic heart failure. N. Engl. J. Med. 2007, 357, 2248-2261. [CrossRef] [PubMed]

263. Gullestad, L.; Ueland, T.; Kjekshus, J.; Nymo, S.H.; Hulthe, J.; Muntendam, P.; Adourian, A.; Böhm, M.; van Veldhuisen, D.J.; Komajda, M.; et al. Galectin-3 predicts response to statin therapy in the Controlled Rosuvastatin Multinational Trial in Heart Failure (CORONA). Eur. Heart J. 2012, 33, 2290-2296. [CrossRef] [PubMed]

264. Price, M.J.; Berger, P.B.; Teirstein, P.S.; Tanguay, J.F.; Angiolillo, D.J.; Spriggs, D.; Puri, S.; Robbins, M.; Garratt, K.N.; Bertrand, O.F.; et al. Standard- vs high-dose clopidogrel based on platelet function testing after percutaneous coronary intervention: The GRAVITAS randomized trial. JAMA 2011, 305, 1097-1105. [CrossRef]

265. Ridker, P.M.; Everett, B.M.; Thuren, T.; MacFadyen, J.G.; Chang, W.H.; Ballantyne, C.; Fonseca, F.; Nicolau, J.; Koenig, W.; Anker, S.D.; et al. Antiinflammatory Therapy with Canakinumab for Atherosclerotic Disease. N. Engl. J. Med. 2017, 377, 1119-1131. [CrossRef] [PubMed] 
266. Januzzi, J.L.; Rehman, S.U.; Mohammed, A.A.; Bhardwaj, A.; Barajas, L.; Barajas, J.; Kim, H.-N.; Baggish, A.L.; Weiner, R.B.; Chen-Tournoux, A.; et al. Use of Amino-Terminal Pro-B-Type Natriuretic Peptide to Guide Outpatient Therapy of Patients with Chronic Left Ventricular Systolic Dysfunction. J. Am. Coll. Cardiol. 2011, 58, 1881-1889. [CrossRef]

267. Newby, D.E.; Adamson, P.D.; Berry, C.; Boon, N.A.; Dweck, M.R.; Flather, M.; Forbes, J.; Hunter, A.; Lewis, S.; MacLean, S.; et al. Coronary CT Angiography and 5-Year Risk of Myocardial Infarction. N. Engl. J. Med. 2018, 379, 924-933. [CrossRef] 